Are Markets Learning?

Behavior in the Secondary Market for Brady Bonds

Luca Barbone

Lorenzo Forni

The World Bank

Europe and Central Asia

Country Department II

Office of the Director

February 1997 
Policy Research Working Paper 1734

\section{Summary findings}

Barbone and Forni analyze some aspects of the market for Brady bonds (restructured debt in developing countries). They focus on how the debt crisis in Mexico in 1994 affected risk assessment (as measured by the stripped spread) in other Brady countries, especially Poland. Their main findings:

- The risk premium (in a single country) has a behavior (one unit ront), consistent with the hypothesis that it reflects new market information.

- Among stripped yiclds, co-movements of sovereign risk premia were stronger during the period of highest volatility in the Mexican crisis. In the case study of Mexico and Poland, they do not reject cointegration for the period July 1994-July 1995, they do reject it for July 1995-July 1996.

- The crisis had a strong permanent effect on risk assessment in Mexico (about 550 basis points).

- Different Brady bonds responded differently to the Mexican crisis. Countries with similar pre-crisis means and volatility reacted similarly (in terms of absolute deviation and the degree of co-movement with the
Mexican bonds). Other factors (region, oil producers, date of Brady deal) did not explain observed patterns.

- There was convergence of volatility during the highly volatile period of the Mexican crisis.

These results suggest that traders' behavior in assessing the sovereign risk of Brady countries is not constant over time, and responds especially to the level of market uncertainty. Herd behavior increases with risk, leading (in a volatile environment) to even more volatility. Learning is likely to spill over because traders have limited experience with, and limited information about, developing countries.

The decrease in co-movements of sovereign risk premia in the second period of the sample could indicate that markets were learning - that is, gathering information about, and experience in, the developing countries, so that the issue of learning spillover was less relevant.

But it could also signal that no relevant shock existed to generate such spillover effects, although the market was still vulnerable to country-specific shocks. On that issue, further research is needed.

This paper - a product of the Office of the Director, Country Department II, Europe and Central Asia - is part of a larger effort in the region to disseminate the findings of cross-country research. Copies of this paper are available free from the World Bank, 1818 H Street NW, Washington, DC 20433. Please contact Luca Barbone, room H11-079, telephone 202473-2556, fax 202-477-1034, Internet address lbarbone(@ worldibank.org. February 1997. (37 pages)

The Policy Rescarch Working Paper Series disseminates the findings of work in progress to encourage the exchange of ideas about development issues. An objective of the series is to get the findings out quickly, even if the presentations are less than fully polished. The papers carry the name's of the authors and should be cited accordingly. The findings, interpretations, and conclusions expressed in this paper are entirely those of the authors. They do not necessanly represent the view of the World Bank, its Executive Directors, or the countries they represent. 


\title{
ARE MARKETS LEARNING? \\ BEHAVIOR IN THE SECONDARY MARKET FOR BRADY BONDS
}

\author{
Luca Barbone \\ Central Europe Department \\ World Bank \\ email: lbarbone@worldbank.org \\ and \\ Lorenzo Forni \\ Department of Economics \\ Boston University \\ Boston, MA 02215 \\ e-mail: lforni@bu.edu
}





\section{Introduction}

In the fall of 1982 the Mexican government announced that Mexico was no longer able to fulfill its external commitments. A run out of developing country debt ensued. It was the first major default of a sovereign country after the crisis of the 1930s, and the event was unexpected, despite the high real interest rate and falling commodity prices that obtained at the time. Most of the debt was held only by several hundred commercial banks.

One of the main inefficiencies associated with the negotiation process that followed was that the "rules of the game" were not clear or predictable. Different strategies were proposed in the $1980 \mathrm{~s}$, ranging from the "involuntary lending" of the early 1980s to the Brady agreements of the past few years. One important milepost in the debt crisis was the introduction of a secondary market in 1985. Since most claims were held by a relatively small group of banks, the market was initially thin. The process of securitization of the developing countries debt, though, accelerated in the last few years.

The Brady agreements are based on the exchange, on a voluntary basis, of commercial debt for a menu of options including bonds or new money - the bond option being the most popular one. Brady agreements have involved debt reductions and have usually been implemented when the debtor country was aiready undergoing economic reforms. Debt reductions and economic reforms have relaxed the credit constraints that were binding for most of the debtors in the 1980s, thereby providing the new market instruments with a relevant degree of liquidity.

As a consequence, the Brady bond market developed very quickly in the past few years. The Emerging Market Trading Association was founded in 1990 (a successor to the earlier "LDC Debt Traders Association"), and by now most bonds are traded continuously all over the world. Trading volumes in 1994 reached US\$2.8 trillion (from US $\$ 100$ billion in 1990), the total amount outstanding of the US dollar-denominated Brady market in 1994 had an approximate face value of US\$138 billion, and future and option market are now traded for all major Bradies. ${ }^{1}$

This impressive development of the secondary market largely resulted from the new approach introduced by the Brady plan. Brady agreements have aimed at and actually led to a securitization of the external debt, to a relaxation of credit constraints and to a restored access to the international financial market. This approach has been consistent with the view that international financial market can be a fair and relatively certain environment to satisfy the financial needs of middle-income countries, probably a better environment than the lasting "bargaining process" that prevailed in the 1980 s.

\footnotetext{
${ }^{1}$ The reader interested in knowing more (daily prices, futures and options, analysis and ratings, news and forum) can now browse the pages of the BradyNet (http://www.2020tech.com/bradynet)
} 
On December 20, 1994 the Mexican peso was devalued by $15 \%$ and two days later it was allowed to float. At the end of December the Mexican government was forced to cancel a Tesobono refinancing auction because investors were no longer willing to bear the sovereign risk at rates acceptable to the Mexican authorities ${ }^{2}$. The perception of sovereign risk - as reflected for example in the Brady bonds prices (see the plots of the Mexican and Polish Par and Discount bond prices in figure 1 and 2) - jumped dramatically during the crisis. Even though the Mexican crisis reflected mainly internal problems, it immediately affected the perception of the sovereign risk in other debtor countries. In particular the yield on most emerging market bonds jumped along with Mexico's. As an example, we report in figure 3 a plot of the stripped spreads ${ }^{3}$ of the Mexican and Polish Brady Discount bonds, and in figure 4 an analogous plot for the Par bonds.

Mexican and Polish Discount Bond Prices

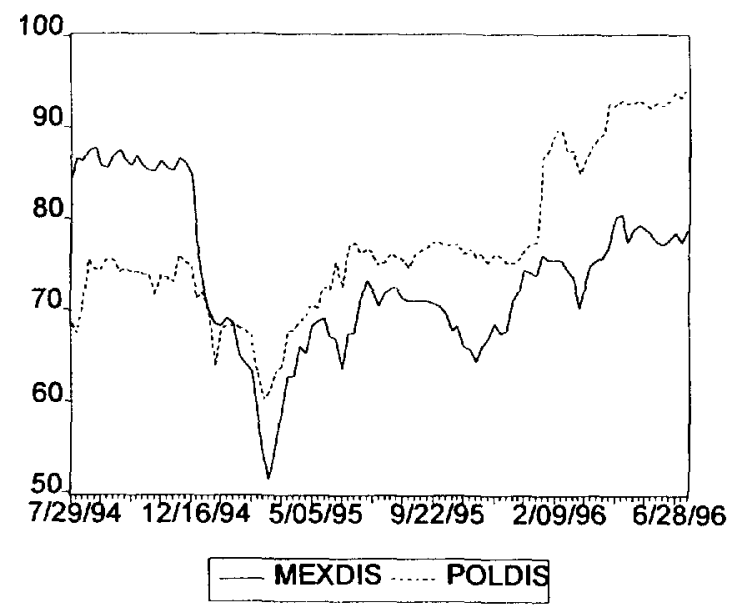

Figure 1
Mexican and Polish Par Bond Prices

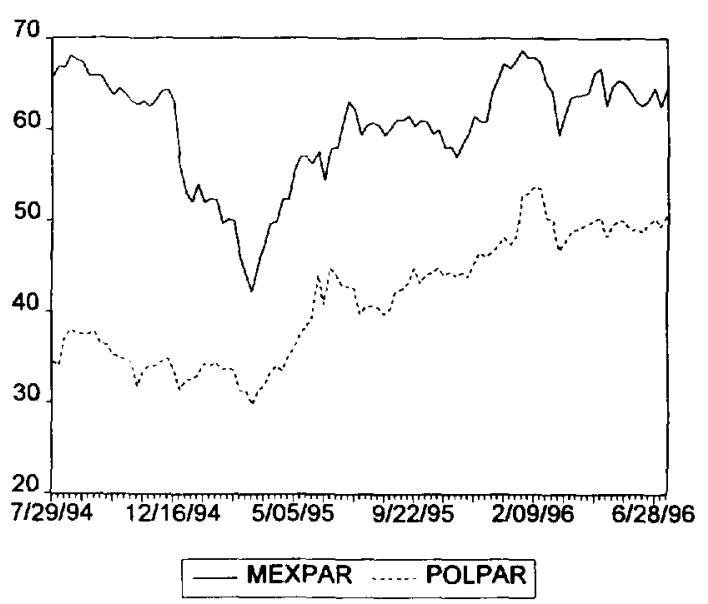

Figure 2

In 1981, the choice not to differentiate among different debtors might have been a rational response to the crisis considering the political and international dimension that that crisis soon reached. This statement could certainly be questioned at end-1994. As long as the international community and the traders believe in the process of debt securitization one would expect that, over time, only country specific elements or international shocks should affect the risk premium of a sovereign country. This paper originated from the initial observation that for the 1994 Mexican crisis there is evidence of spillover effects in the assessment of the sovereign risk premium for different countries. The questions we will try to address are the following: Are there comovements (not due to international shocks) in the sovereign risk premium of different debtor countries? If there are, what is the nature and the dimension of these comovements? To what extent can a leader country like Mexico affect the risk perception on

\footnotetext{
${ }^{2}$ For an assessment of the Brady deal on Mexico the reader can see Claessens, S., D. Oks and S. van Wijnbergen (1993). For an account of the 1994 Mexican debacle see Calvo, G.A. (1996).

${ }^{3}$ The reader not familiar with this term can refer to the Appendix.
} 
other debtor countries? Why should the developing country debt market be affected by these spillovers? And why should it be more affected than the industrial countries debt market? What can we learn on traders' behavior in the Brady bond market?

\section{Mexico and Poland, Discount Bonds}

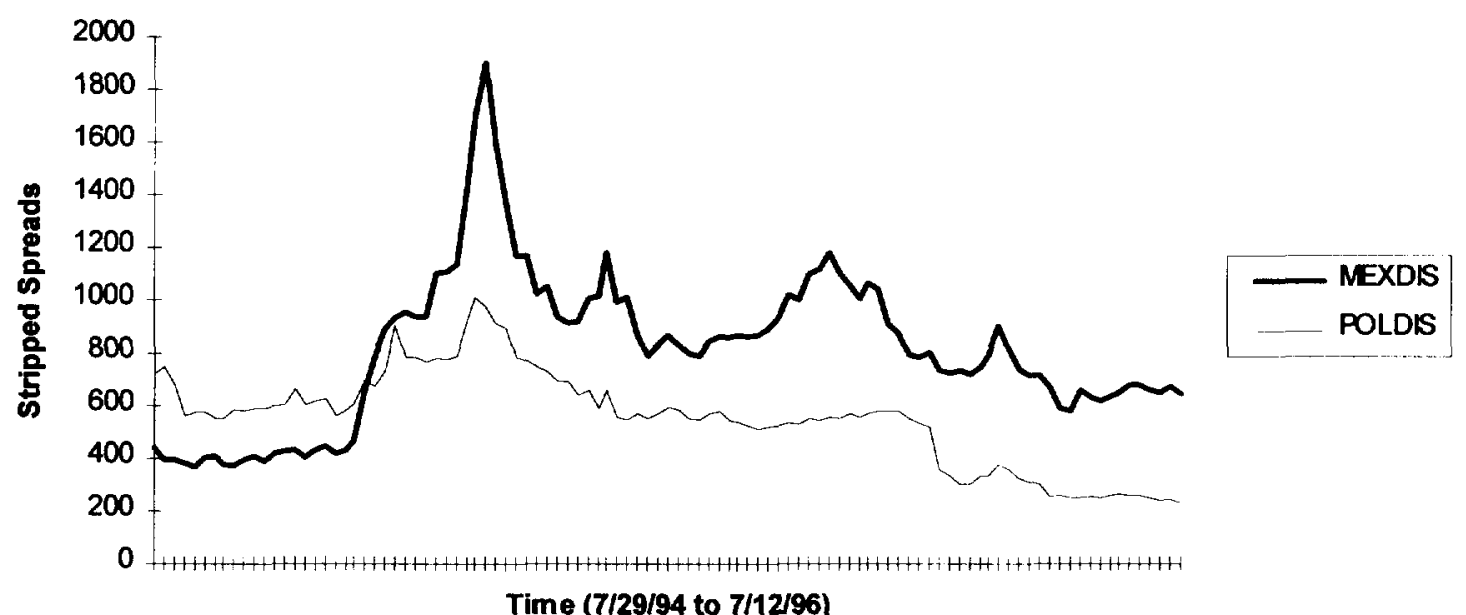

Figure 3

\section{Mexico and Poland, Par Bonds}

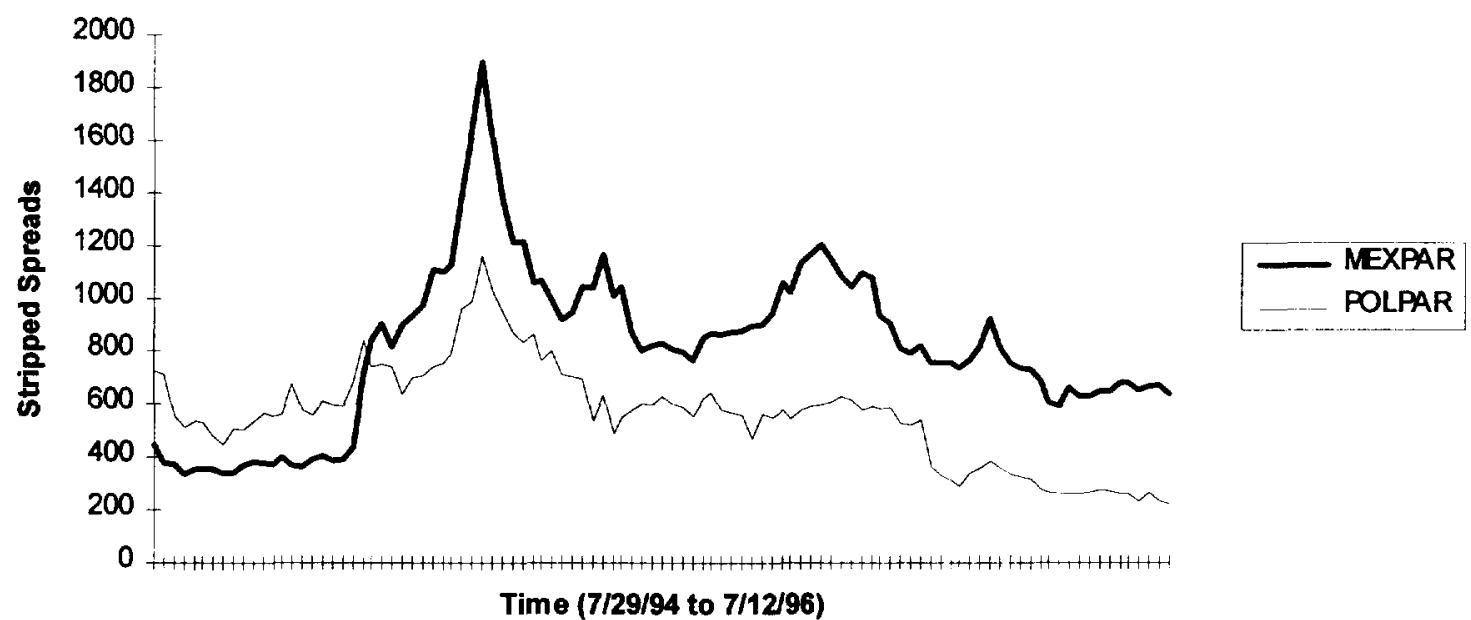

Figure 4 
A finding of relevant spillovers would have many implications and would be especially important to the countries that have a substantial commitment to the reform process. If the payoff - in terms of costs of external financing - of a serious commitment to a reform process can be substantially reduced by spillover effects, the incentives to stick to the reform process can be reduced as well.

The paper is organized as follows. Section 2 provides a brief review of the literature. Section 3 describes the data set. Section 4 reports the analysis of comovements, focusing on the case of Mexico and Poland. In section 5 we develop an interpretation of the results of Section 4 and in Section 6 we test this interpretation. Section 7 concludes.

\section{Pricing risky debt}

In this section we briefly review the existing literature on the Brady bond market. We do so by dividing the literature based on the three different approaches generally used to price risky debt: option theory, fundamentals and spillover effects. The option theory approach is the most widely used (also by traders) to price corporate (i.e. risky) debt and constitutes a complete theory on its own. On the other hand the approaches based on fundamentals and spillover effects should be thought as complementary, as it will result clear in the following sections.

Option theory. Option theory is generally used to price the debt of corporate companies. Let $D$ denote the market value of the corporation's promise to pay the amount $F$ in $t$ years, let $S$ denote the market value of the firm's common stock, and let $A$ denote the current market value of the assets of the corporations. The Modigliani-Miller ${ }^{4}$ theorem asserts that:

$A=D+S$

Given this structure, it is easy to see that the corporation's common stock can be interpreted as a call option on the assets of the corporation, with an exercise price of $F$ and time of expiration of $t$. In fact, when the debt matures, the stockholders can either pay $F$ to the creditors (exercise the option) and keep control over the assets, or default on the debt (not exercise the option) and let the creditors take control over the assets of the corporation.

Because the common stock of the corporation looks like a call option, we can apply the Black and Scholes options pricing model to find a theoretical value for $S$. Given (1), we can get a theoretical price for $D$ which will depend on the following variables: $A$ (the current market value of the assets of the corporation), $F$ (the face value of the debt), $t$ (the time remaining to the maturity of the debt), the risk-free interest rate and the volatility of the value of the assets of the corporation. At the maturity date the option will be exercised if $A$ is greater than $F$. So, before the maturity

\footnotetext{
${ }^{4}$ Modigliani and Miller (1958) first asserted that the value of a firm should be independent of its capital structure.
} 
date, the ratio $A / F$, the volatility of $A$ and the time remaining to the maturity of the debt (together with the levels of $A, F$ and, of course, the risk-free interest rate) enter the determination of the price. An application of this approach to the debt of a sovereign nation has been proposed by Claessens and Van Wijnbergen (1993), who use option theory to price the bonds of the Mexico Brady deal. ${ }^{5}$

Fundamentals. A different approach tries to relate secondary market debt prices to a set of explanatory variables, such as debt to export ratio, reserves to import ratio, inflation, etc. (e.g. Cohen (1989), Ozler and Huizinga (1991)) or on the past history of repayments (e.g. Hajivassiliou (1989), Ozler (1993)). These studies have generally tried to identify variables that best explain repayment capacity by conducting econometric tests on goodness-of-fit. It is in fact extremely difficult to have a well specified and testable theory on the likelihood of repayment as a function of the fundamentals: the likelihood of repayment will depend on factors that affect both the ability and willingness to pay, as well as the bargaining power in case of rescheduling or recontracting. A very rich theoretical literature, started by Eaton and Gersovitz (1981), has pointed out the complexity of the strategic issues involved in lending to a sovereign country. Furthermore, these analyses usually make the implicit assumption that bonds of different countries traded on the secondary market are directly comparable so that the available prices can be used in cross country regressions. This is true if we restrict the attention to Par and Discount Brady bonds, as we do. But most of the cited studies use typically pre-Brady or non-Brady prices.

Spillover effects. The approach based on spillover effects simply states that the level or the variation of the price of a particular bond in the market depends on the behavior of similar bonds. For example, the IMF (1995) reports tests of causality that support the null hypothesis that the price of the Mexican Brady bonds Granger causes the price of other Brady countries, like Venezuela and Brazil. Similarly, Doukas (1989) and Calvo and Reinhart (1996) argue that there is evidence of 'contagion effects' on Brady bonds returns following news on the production or shocks like the Mexican crisis respectively. Eichengreen (1989) concludes in his study 'The U.S. Capital Market and Foreign Lending, 1920-1955' that "evidence from bond prices in the 1930s and from the volume and composition of lending in the 1940s and 1950s suggest that at least some of the cost of default spilled over among debtor countries." Certainly spillover effects can only partially explain bond prices and in this sense they are complementary to fundamentals in the explanation of bond prices and returns.

\footnotetext{
5 The value of $A$ for a sovereign country is not obvious, and an estimate of that value is going to be approximate and subjective. Claessens and van Wijnbergen assume a stochastic behavior for the value correspondent to $A$. They assume a Brownian motion, that is a continuous version of a random walk, but there is no clear evidence for such a behavior of the underlying stochastic element. It should also be noted that the option theory approach subsumes all the information on the fundamentals in the value of $A$ (which should represent the capacity or willingness to pay in case of default) and in its stochastic behavior. It does not model explicitly the effects of the fundamentals or of possible spillover effects.
} 
In this paper we focus on spillover effects in the Brady bond market. A lot can be learnt from a careful analysis of these effects. As in the introduction, these are the question we will assess: Are there comovements (not due to international shocks) in the sovereign risk premium of different debtor countries? If there are, which is the nature and the dimension of these comovements? To what extent can a leader country like Mexico affect the risk perception on other debtor countries? Why should the developing country debt market be affected by these spillovers? And why should it be more affected than the industrial countries debt market? What can we learn on traders' behavior in the Brady bond market?

\section{The data set}

We will focus on the sovereign credit risk as measured by the sovereign (stripped) spread. ${ }^{6}$ The sovereign spread is a measure that analysts use to assess the risk of a bond and it is given by the yield differential of a developing country bond with respect to an analogous (in terms of type of contract and maturity) US Treasury Bond, which is considered a riskless asset? .

\footnotetext{
${ }^{6}$ Risk is often defined as the probability associated with a loss. In general risk can take many forms: credit risk (estimates potential losses due to the inability of the counterpart to meet its obligations), operational risk (results from the errors that can be made in instructing payments or settling transactions), liquidity risk (associated with the inability of the debtor to fund illiquid assets) and market risk (uncertainty of earnings resulting from changes in market conditions such as prices, interest rates, volatility).

For stocks and bonds in industrial countries the relevant risk usually is the market risk: the volatility of the prices measures the risk of holding a stock (which has no maturity), while expected changes in interest rates define the shape of the yield curve for bonds. For developing countries (as well as for all issuers with a low credit rating) the most important risk is the credit risk: this is because a sovereign country by definition cannot be legally forced to comply with its external commitments.

${ }^{7}$ To be rigorous the credit risk should be split into two parts: one is the probability of default and the other is the amount of loss in case of default. For example, it would be of interest to compute the internal rate of return (yield) on a bond based on what are the expected payments instead of the contractual ones. The differential to an analogous riskless asset would than be a proper measure to infer the probability of default. The authors that have attempted to differentiate between the two elements (i.e. the probability of default and the amount of loss in case of default), however, are forced to make strong assumptions on the probability of default and on the expected repayment in case of default. For example Cumby, R.E. and D.D. Evans (1993) assume that in case of default the repayments are zero forever. Claessens, S. and G. Pennacchi (1992) assume that the probability of default follows a Brownian motion . An interesting finding of Cumby and Evans (1993) though - on which we will return below - is that the hypothesis of an expected decreasing default probability is consistent with their data set (Brady bonds prices starting 1990 for Mexico, Venezuela and Costa Rica).
} 
TABLE 1. Sample description.

\begin{tabular}{|c|c|c|c|c|c|c|}
\hline Country $^{8}$ & Bond & $\begin{array}{l}\text { Terms } \\
\text { Announced }\end{array}$ & $\begin{array}{l}\text { Issue } \\
\text { Date }\end{array}$ & $\begin{array}{l}\text { Maturity } \\
\text { Date }\end{array}$ & Ratings 9 & Liquidity $^{10}$ \\
\hline 1) Argentina (18\%) & $\begin{array}{l}\text { Pars } \\
\text { Discounts }\end{array}$ & Apr 1992 & $\begin{array}{l}4 / 07 / 93 \\
4 / 07 / 93\end{array}$ & $\begin{array}{l}3 / 31 / 23 \\
3 / 31 / 23\end{array}$ & B1, BB- & $\begin{array}{l}\mathrm{L} 1 \\
\mathrm{~L} 2+\end{array}$ \\
\hline 2) Brazil (35\%) & $\begin{array}{l}\text { Pars }(A, B) \\
\text { Discounts }(A, B)\end{array}$ & Jul 1992 & $\begin{array}{l}4 / 15 / 94 \\
4 / 15 / 94\end{array}$ & $\begin{array}{l}4 / 15 / 24 \\
4 / 15 / 24\end{array}$ & $\mathrm{~B} 1, \mathrm{~B}+$ & $\begin{array}{l}\text { L1- } \\
\text { L2 }\end{array}$ \\
\hline 3) Mexico (19\%) & $\begin{array}{l}\text { Pars (A, B) } \\
\text { Discounts (A, B, C }\end{array}$ & Jan 1990 & $\begin{array}{l}3 / 28 / 90 \\
3 / 28 / 90\end{array}$ & $\begin{array}{l}12 / 31 / 19 \\
12 / 31 / 19\end{array}$ & $\mathrm{Ba} 2, \mathrm{BB}$ & $\begin{array}{l}\mathrm{L} 1 \\
\mathrm{~L} 2+\end{array}$ \\
\hline 4) Venezuela ( $12 \%)$ & $\begin{array}{l}\text { Pars (A, B) } \\
\text { Discounts }\end{array}$ & Jun 1990 & $\begin{array}{l}12 / 18 / 90 \\
12 / 18 / 90\end{array}$ & $\begin{array}{l}3 / 31 / 20 \\
3 / 31 / 20\end{array}$ & $\mathrm{Ba} 2,--$ & $\begin{array}{l}\text { L1- } \\
\text { L3 }\end{array}$ \\
\hline 5) Ecuador (1.8\%) & $\begin{array}{l}\text { Pars } \\
\text { Discounts }\end{array}$ & May 1994 & $\begin{array}{l}2 / 28 / 95 \\
2 / 28 / 95\end{array}$ & $\begin{array}{l}2 / 28 / 25 \\
2 / 28 / 25\end{array}$ & n.r., n.r. & $\begin{array}{l}\text { L2 } \\
\text { L2 }\end{array}$ \\
\hline 6) Bulgaria (4\%) & Discounts (A) & Mar 1994 & $7 / 28 / 94$ & $7 / 28 / 24$ & n.r., n.r. & $\mathrm{L} 2$ \\
\hline 7) Poland (6\%) & $\begin{array}{l}\text { Pars } \\
\text { Discounts }\end{array}$ & Mar 1994 & $\begin{array}{l}10 / 27 / 94 \\
10 / 27 / 94\end{array}$ & $\begin{array}{l}10 / 27 / 24 \\
10 / 27 / 24\end{array}$ & Ваa3, BBB- & $\begin{array}{l}\mathrm{L} 2 \\
\mathrm{~L} 2+\end{array}$ \\
\hline 8) Nigeria $(0.9 \%)$ & Pars & Oct 1991 & $1 / 21 / 92$ & $11 / 15 / 20$ & n.r., n.r. & L2 \\
\hline 9) Philippines (3\%) & Pars (B) & Feb 1992 & $12 / 01 / 92$ & $12 / 01 / 17$ & $\mathrm{Ba} 2, \mathrm{BB}$ & L2- \\
\hline
\end{tabular}

\footnotetext{
${ }^{8}$ Up to now, the other Brady agreements are: Costa Rica (Terms announced: May 90, Issue date: 5/21/90), Uruguay (Terms announced: Nov 90, Issue date: 2/18/91), Jordan (Terms announced: Jan 93, Issue date: 12/23/93) and Dominican Republic (Terms announced: Aug 93, Issue date: $8 / 30 / 94)$.

9 Moody's, Standard and Poor's respectively. The rating are as June 21, 1996. The following table summarizes the grade rank:

\begin{tabular}{|c|c|c|c|c|}
\hline \multicolumn{3}{|c|}{ Investment grade } & \multicolumn{2}{|c|}{ Speculative grade } \\
\hline Moody & S\&P & & Moody & S\&P \\
\hline Aaa & AAA & & $\mathrm{Bal}$ & $\mathrm{BB}+$ \\
\hline Aal & $\mathrm{AA}^{+}$ & & $\mathrm{Ba} 2$ & BB \\
\hline $\mathrm{Aa} 2$ & $\mathbf{A A}$ & & $\mathrm{Ba3}$ & BB- \\
\hline $\mathrm{Aa} 3$ & AA- & BI & B+ & \\
\hline Al & At & & B2 & B \\
\hline A2 & A & & B3 & B- \\
\hline A3 & A- & & & \\
\hline Baal & BBB + & & & \\
\hline Ваa2 & BBB & & & \\
\hline $\mathrm{Baa} 3$ & BBB- & & & \\
\hline
\end{tabular}
}

n.r. $=$ not rated. Note: Baal/BBB+ or below is the rating requirement designed by JPMorgan to define an "emerging market" in the context of external debt market. Source: JPMorgan, Emerging Market Analytics, June 211996.

${ }^{10}$ The liquidity rating for Brady bonds provided by JPMorgan is:

L1 Benchmark Average bid/offer $<3 / 8$ and bond quoted by the main brokers.

L2 Active Average bid/offer $<3 / 4$ and bond quoted by at least half of the main brokers.

L3 Traded Average bid/offer $<2$ and bond quoted by at least one main broker.

L4 Mostly Illiquid Average bid/offer $<3$ and bond quoted by at least one main broker.

L5 Illiquid Bond rarely or never quoted by main brokers.

Note: A bond is considered quoted in categories L1, L2 and L3 if it is priced $75 \%$ of the time; it is considered quoted in category L4 if it is priced $25 \%$ of the time. The main brokers designed by JPMorgan are: Eurobrokers, Tullets, Tradition, Cantor, Chapdelaine and RMJ.

Source: JPMorgan, Introducing the Emerging Markets Bond Index Plus. July 12, 1995.

$11 \%$ of total amount outstanding in the Brady Market in parenthesis. Source: Merril Lynch, The 1995 Guide to Brady Bonds, $12 / 06 / 94$. 
The data set is summarized in Table 1 and figure 5. We took fifteen Par and Discount Brady bonds for nine major Brady agreements. The choice of bonds has been driven by criteria of liquidity (see the last column of the Table 1) and homogeneity. ${ }^{12}$
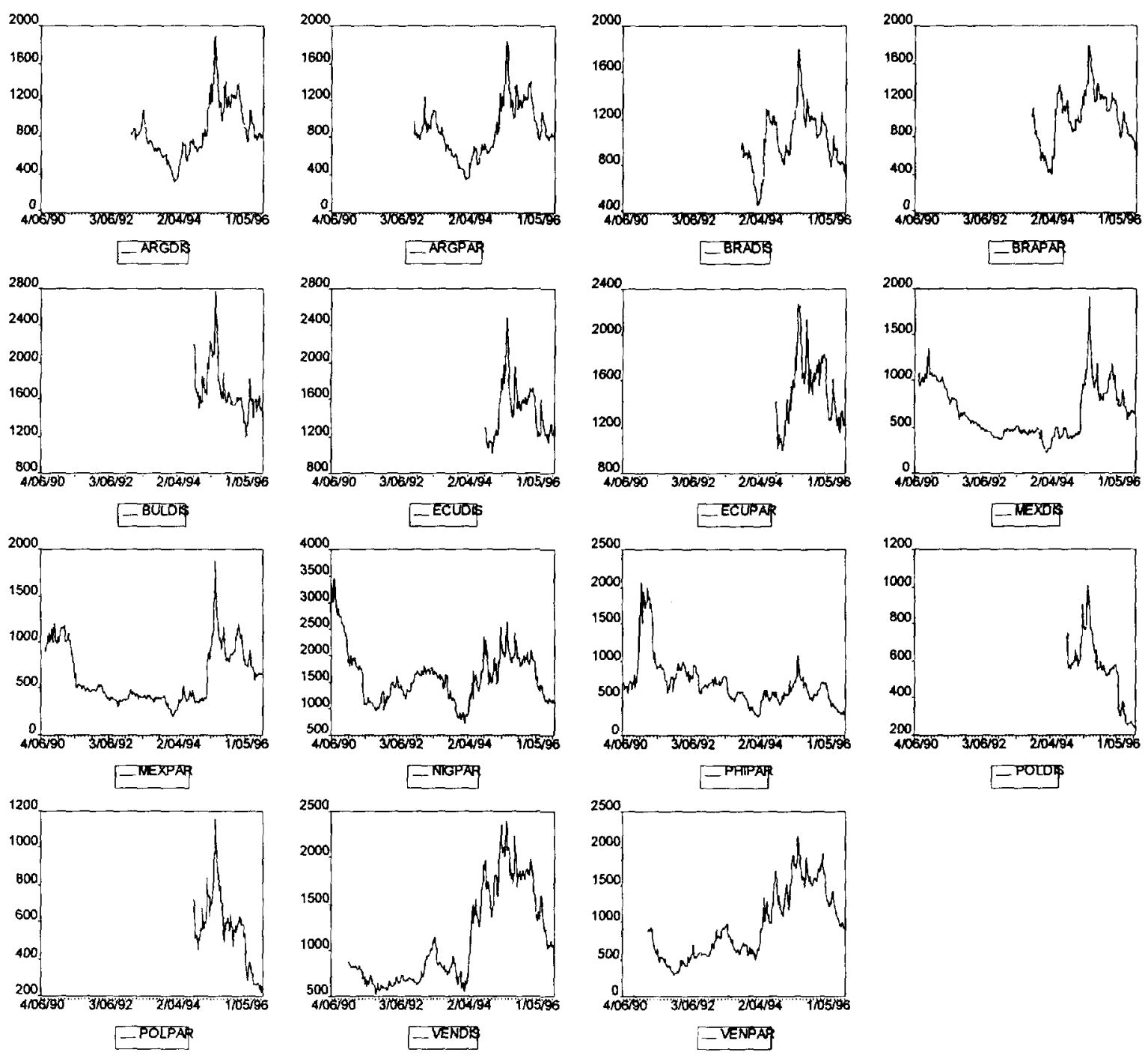

Figure 5

We concentrate on the sovereign (stripped) spreads for several reasons. First, we want to exclude the effects of changes in the (same maturity) US interest rates on yields comovements. Note that, if the solvency of a country is in doubt, an increase in the US interest rate can have an effect on the sovereign premium as well. But we would expect

\footnotetext{
${ }^{12}$ The data are provided by Salomon Brothers and are based on weekly (usually Wednesday) close of the day bid prices quoted in NY. We have data beginning on the week Salomon Brothers has started trading on the loans included in the Brady agreements, even though the bonds have been in all cases formally issued few months later. At this point we suggest to the reader not familiar with the Brady bond market to have a look at the Appendix.
} 
this effect to be of second order and not homogeneous among the different countries of our sample. Moreover, the US interest rate has been much more smooth than the risk premiums over the period of our study, as figure 6 shows for Mexico and Poland.
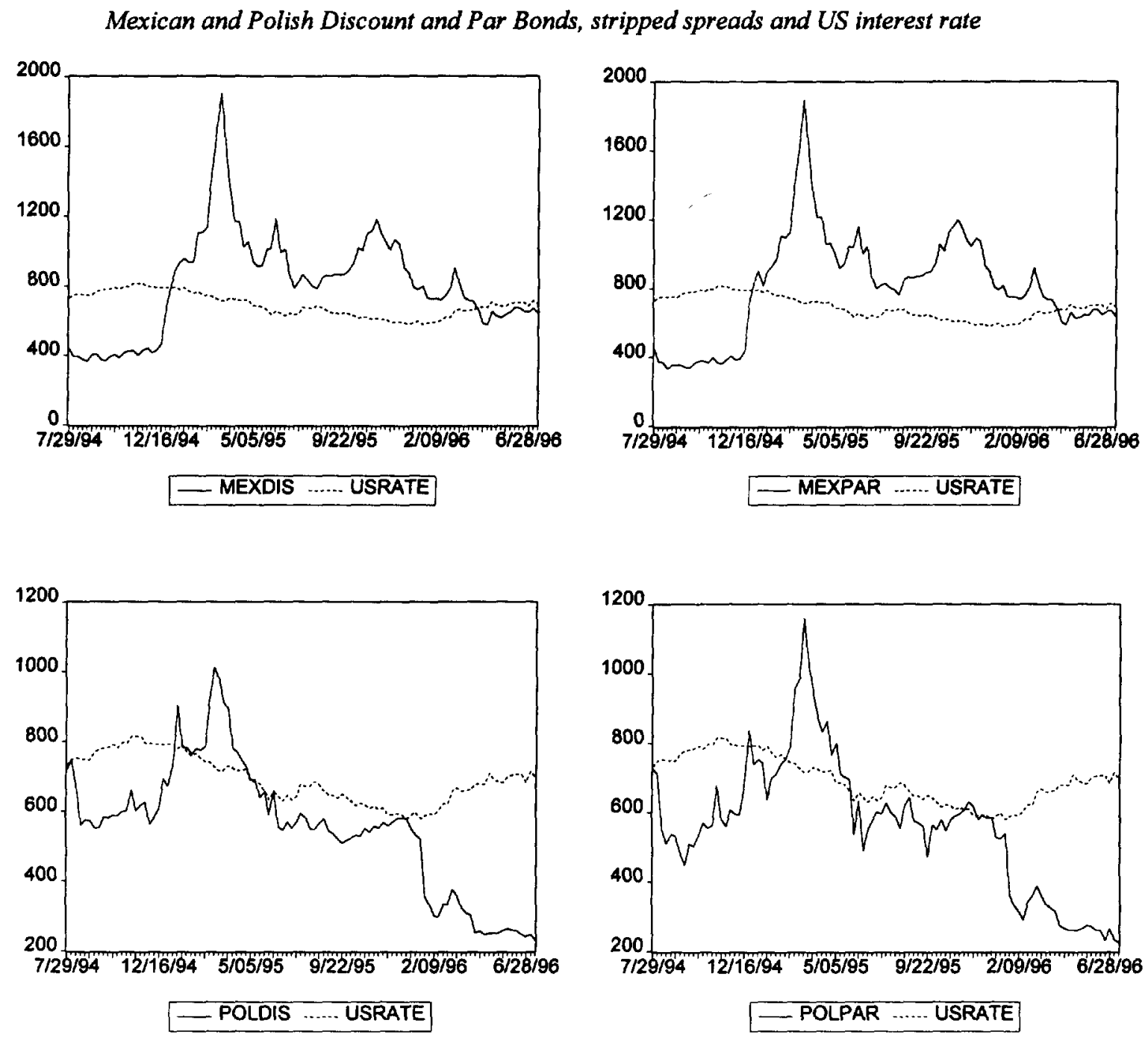

Figure 6

Second, even if the stripped spread is a rough measure of the country risk, we are in fact interested in cross-country comparisons. For us, it is more important to have a very homogeneous measure, as we believe it is the stripped spread on the most liquid Brady bonds.

Third, it would be ideal to have time series of the risk spread for given maturity instead of following the same bonds over time. However, the Brady market has not reached the dimension to make this possible. The point is that yields spreads may not provide a valid way of comparing the relative risks of bonds with different maturities. But the 
maximum maturity difference for the Mexican Brady bonds is slightly more than 5 years (with the last Brady, Ecuador) over a period of 24 years. The effect of a different maturity is important for short maturities and it is a much less relevant factor over such a long time horizon.

\section{Mexico and Poland}

It is our opinion that the case of Mexico and Poland is the most suitable for the analysis of spillover effects in the Brady bond market: Mexico at the time of the crisis was a relatively stable country; Poland was stabilizing and had a relatively short record of economic reforms. The December 94 shock was substantial, but truly originating from the Mexican economy and in this sense it was exogenous to the Poland economy. This can be thought as a good approximation of an experiment: the Mexican fundamentals were dramatically changed while Poland's were not.

We will concentrate on the discount bonds: discount bonds are 30 years maturity floating market interest rate, issued at a discount to the original face value of the previously rescheduled loans. Because they are floating market interest rate, discount bonds do not involve market risk (the risk of a change in the interest rate), so that the measure of country risk given by the stripped spread on discount bonds is more accurate than the one given by the stripped spread on the Par bonds.

\subsection{Univariate time series description}

In this section we report the time series analysis on the variable MEXDIS (the stripped spread on the Mexican discount bonds (series A,B,C,D)), and on the variable POLDIS (the stripped spread on the Poland discount bonds). The goal is to have a preliminary understanding of the behavior of the stripped spread, that is the measure that traders use for the risk premium on a sovereign country bond. The main finding is that we cannot reject the null hypothesis of unit root for both variables, even if also a different (and stationary) model fits well the data.

i) $M E X D I S$ (the sample goes from $5 / 18 / 90$ to $7 / 12 / 94$ )

1) The first model is an AutoRegressive with four lags - AR(4) - with one unit. The Augmented Dickey-Fuller Test on the whole sample is -1.134891 , so we do not reject the null of unit root even at a $10 \%$ confidence level. ${ }^{13}$ An $\mathrm{AR}(4)$ with one unit root behaves like a random walk in the sense that the shocks have a permanent effect; in the case of the AR(4), the shocks are translated permanently into the variable after 4 periods. To decide on the model specification for the Augmented Dickey-Fuller (ADF) test for unit root, we performed an $F$ test - the values are

\footnotetext{
${ }^{13}$ We reject the null of autocorrelation of the residuals based on the Breusch-Godfrey Serial Correlation LM Test.
} 
tabulated in Dickey and Fuller (1981) - on the joint hypotheses of unit root with no drift and no trend. We cannot reject the null of unit root without drift and trend.

\begin{tabular}{|c|c|c|c|c|c|}
\hline \multicolumn{6}{|c|}{$\begin{array}{l}\text { LS // Dependent Variable is MEXDIS } \\
\text { Sample: } 6 / 15 / 90-7 / 12 / 96 \\
\text { Included observations: } 318\end{array}$} \\
\hline Variable & Coefficient & \multicolumn{2}{|c|}{ Std. Error } & T-Statistic & Prob. \\
\hline $\operatorname{MEXDIS(-1)~} 1.251$ & 1.251215 & \multicolumn{2}{|c|}{0.055527} & 22.53350 & 0.0000 \\
\hline $\operatorname{MEXDIS}(-2) \quad-0.222$ & -0.222751 & \multicolumn{2}{|c|}{0.088032} & -2.530349 & 0.0119 \\
\hline $\operatorname{MEXDIS}(-3)-0.193$ & -0.193206 & \multicolumn{2}{|c|}{0.087332} & -2.212301 & 0.0277 \\
\hline $\operatorname{MEXDIS}(-4) \quad 0.159$ & 0.159970 & \multicolumn{2}{|c|}{0.054736} & 2.922590 & 0.0037 \\
\hline R-squared & \multicolumn{2}{|c|}{0.964241} & \multicolumn{2}{|c|}{ Mean dependent var } & 657.8306 \\
\hline Adjusted R-squared & \multicolumn{2}{|c|}{0.963899} & \multicolumn{2}{|c|}{ S.D. dependent var } & 282.6279 \\
\hline S.E. of regression & \multicolumn{2}{|c|}{53.69972} & \multicolumn{2}{|c|}{ Akaike info criterion } & 7.979314 \\
\hline Sum squared resid & \multicolumn{2}{|c|}{905469.2} & \multicolumn{2}{|c|}{ Schwartz criterion } & 8.026636 \\
\hline Log likelihood & \multicolumn{2}{|c|}{-1715.933} & \multicolumn{2}{|c|}{ F-statistic } & 2822.343 \\
\hline Durbin-Watson stat & \multicolumn{2}{|c|}{1.969546} & \multicolumn{2}{|c|}{ Prob(F-statistic) } & 0.000000 \\
\hline
\end{tabular}

This model is, in our opinion, consistent with the nature of the variable we are studying: it would be difficult to argue that the stripped spread should have a drift and/or a trend. On the other hand, the finding of unit root is consistent with the hypothesis that there is a learning process underlying risk premium movements: we can think of a shock as new information accruing between one period and the following; based on the new information traders update their prior on the probability of default, and set the risk premium based on the posterior probability. So the new information affects permanently the risk premium and its mean value. This is a layman's explanation of a unit root. $^{14}$

\footnotetext{
${ }^{14}$ While the evidence of one unit root - we tested also the possibility of more than one unit root using the procedure proposed by Dikey and Pantula (1987); the null of two unit root is rejected - is strong on the complete sample, we wanted to check if the December 1994 crises represent a structural break that can cause a bias in our estimate of the unit root. We divided the sample in two (4/06/90 to 12/16/94 and 12/23/94 to 7/12/96) and performed unit root test on the two sub-samples. For the first sub-period, using $F$ tests as tabulated by Dikey and Fuller (1981), we could not reject (at the 5\% confidence level) the null of one unit root with no drift and no trend. If we maintain our hypothesis of no drift and no time trend, there is strong evidence of unit root also for the second sub-period. However, we performed an $F$ test on the joint hypothesis of unit root with no drift and no trend and we rejected it. An ADF with drift and trend leads to rejection of unit root at the $5 \%$ critical level - but to not rejection at the $1 \%$ critical level .

In conclusion, the hypothesis of unit root is strong on the complete sample. On the two sub-samples it is less strong. But under the hypothesis of no drift and no trend, in both cases we could not reject (at the $5 \%$ critical value) the null of unit root.

To gain more information on the possibility of unit root, we constructed two dummy variables: one $(d l)$ takes value one after $12 / 16 / 94$ and zero before that date; the other $(d p)$ takes value one for (the four observations of) the month of December 1994 and zero otherwise. We regress MEXDIS on four lags of itself and on $d l$; in a second regression we regress MEXDIS on the same four lags and on $d p$. The idea is that, if the true model is a stationary process with a structural change in the mean after December 1994, $d /$ should be significant. But it is not. While, if the true model is non stationary and there is a one time extra-shock in a unit root process (a single pulse in the dummy variable will have a permanent effect on the mean value of the sequence), $d p$ should be significant. In fact it is
} 
2) The second model assumes that the variable is stationary with a change in the mean after $12 / 16 / 94$. This is suggested by inspection of the plot of MEXDIS. The variable can be described by a decreasing trend with a change in the constant after the December crisis. We estimated the following model, where the dummy $d 1$ takes value one after $12 / 16 / 94$ and zero before that date:

$$
M E X D I S=c+\alpha t+\beta d l+\sum_{i=1}^{4} \gamma_{i} \operatorname{MEXDIS(-i)}
$$

The results are:

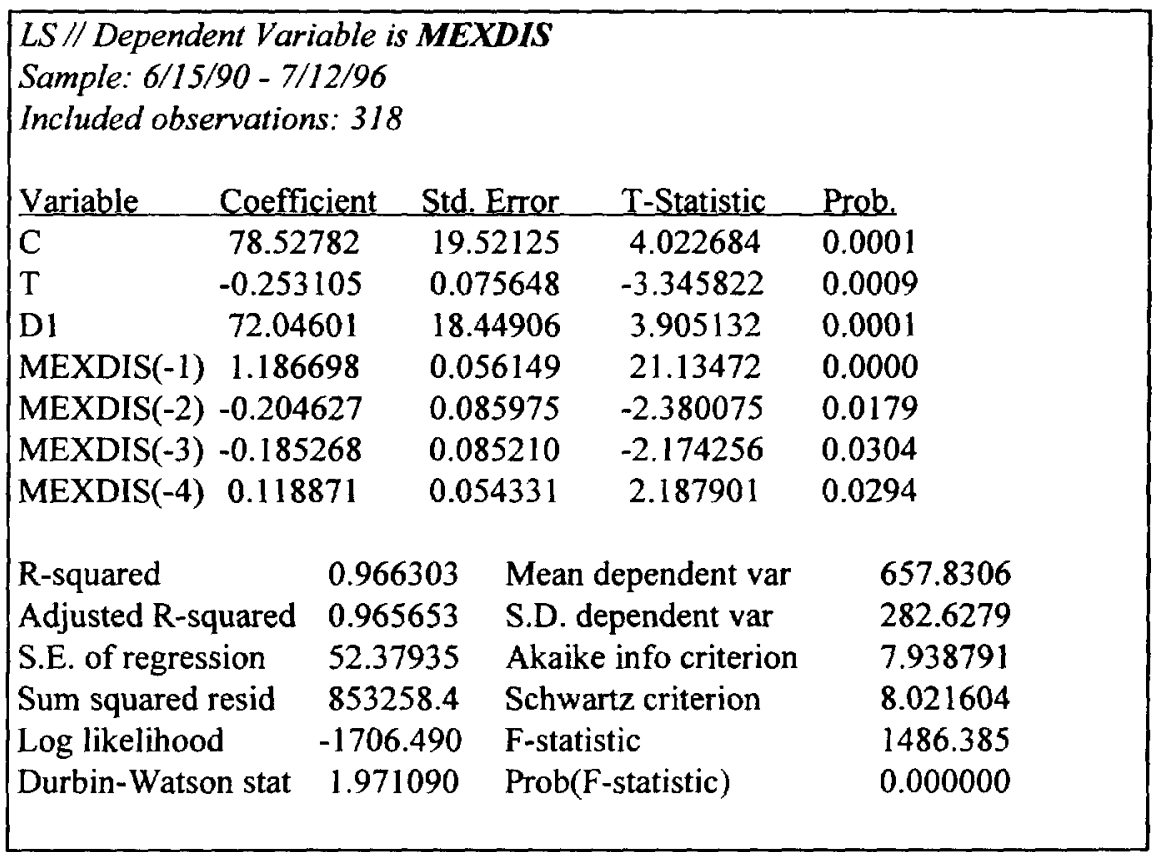

The drift, the trend and the dummy $d l$ are very significant. An ADF based on this model suggests the rejection of the null of unit root. ${ }^{15}$

ii) POLDIS (sample: $7 / 29 / 94$ to $7 / 12 / 96$ ).

1) The first model is a simple random walk, that is an AR(1) with one unit root. The evidence for unit root is very strong. ${ }^{16}$ The value of the Dickey-Fuller Test Statistic is -1.264866 , while the $10 \%$ critical value is -1.6174 .

\footnotetext{
15 In order to perform a proper test, we split the sample as before: $4 / 06 / 90$ to $12 / 16 / 94$ and 12/23/94 to $7 / 12 / 96$. For the first sub-period the drift and the trend are not significant and there is strong evidence of unit root. For the second period, drift and trend are significant and we can reject the null of unit root at the $5 \%$ critical level.

${ }^{16}$ The evidence of unit root is maintained if we split the sample at 12/16/94 as for MEXDIS.
} 


\begin{tabular}{|c|c|c|c|c|c|}
\hline \multicolumn{6}{|c|}{$\begin{array}{l}\text { LS // Dependent Variable is POLDIS } \\
\text { Sample: } 8 / 05 / 94-7 / 12 / 96 \\
\text { Included observations: } 102\end{array}$} \\
\hline \multicolumn{2}{|c|}{ Variable Coefficient } & \multicolumn{2}{|c|}{ Std. Error } & T-Statistic & Prob. \\
\hline \multicolumn{2}{|c|}{ POLDIS(-1) 0.990426} & \multicolumn{2}{|c|}{0.007569} & 130.8552 & 0.0000 \\
\hline R-squared & \multicolumn{2}{|c|}{0.941135} & \multicolumn{2}{|c|}{ Mean dependent var } & 551.8529 \\
\hline Adjusted R-squared & \multicolumn{2}{|c|}{0.941135} & \multicolumn{2}{|c|}{ S.D. dependent var } & 184.4645 \\
\hline S.E. of regression & \multicolumn{2}{|c|}{44.75499} & \multicolumn{2}{|c|}{ Akaike info criterion } & 7.612161 \\
\hline Sum squared resid & \multicolumn{2}{|c|}{202303.9} & \multicolumn{2}{|c|}{ Schwartz criterion } & 7.637896 \\
\hline Log likelihood & \multicolumn{2}{|c|}{-531.9520} & \multicolumn{2}{|c|}{ Durbin-Watson stat } & 2.008243 \\
\hline
\end{tabular}

2) The second model is similar to the second one for MEXDIS:

$$
P O L D I S=c+\alpha t+\beta d 1+\gamma \text { POLDIS(-1) }
$$

The results are:

\begin{tabular}{|c|c|c|c|c|c|}
\hline \multicolumn{6}{|c|}{$\begin{array}{l}\text { LS// Dependent Variable is POLDIS } \\
\text { Sample: } 8 / 05 / 947 / 12 / 96 \\
\text { Included observations: } 102\end{array}$} \\
\hline Variable & Coefficient & \multicolumn{2}{|c|}{ Std. Error } & T-Statistic & Prob. \\
\hline 504.6 & 504.6681 & \multicolumn{2}{|c|}{127.1812} & 3.968103 & 0.0001 \\
\hline-1.665 & -1.665897 & \multicolumn{2}{|c|}{0.419320} & -3.972849 & 0.0001 \\
\hline 75.10 & 75.10052 & \multicolumn{2}{|c|}{21.39856} & 3.509606 & 0.0007 \\
\hline POLDIS(-1) & 0.802494 & \multicolumn{2}{|c|}{0.050719} & 15.82226 & 0.0000 \\
\hline R-squared & \multicolumn{2}{|c|}{0.949392} & \multicolumn{2}{|c|}{ Mean dependent var } & 551.8529 \\
\hline \multirow{2}{*}{$\begin{array}{l}\text { Adjusted R-squared } \\
S E \text { of regression }\end{array}$} & \multicolumn{2}{|c|}{0.947843} & \multicolumn{2}{|c|}{ S.D. dependent var } & 184.4645 \\
\hline & \multicolumn{2}{|c|}{42.12772} & \multicolumn{2}{|c|}{ Akaike info criterion } & 7.519838 \\
\hline Sum squared resid & \multicolumn{2}{|c|}{173925.0} & \multicolumn{2}{|c|}{ Schwartz criterion } & 7.622778 \\
\hline Log likelihood & \multicolumn{2}{|c|}{-524.2435} & \multicolumn{2}{|c|}{ F-statistic } & 612.8235 \\
\hline Durbin-Watson stat & \multicolumn{2}{|c|}{1.960488} & \multicolumn{2}{|c|}{ Prob(F-statistic) } & 0.000000 \\
\hline
\end{tabular}

where $d l$ is defined as above (dummy with ones after 12/16/94). An ADF on the complete sample based on this model (i.e. with drift and trend) suggests the rejection of the null of unit root at the $5 \%{ }^{17}$

\footnotetext{
${ }^{17}$ In order to perform a proper ADF test, we split the sample as above: $7 / 29 / 94$ to $12 / 16 / 94$ and $12 / 23 / 94$ to $7 / 12 / 96$. For the first period we cannot reject the null of unit root even at the $10 \%$ level. For the second period, we reject the null of unit root at the $5 \%$ critical level.
} 
Conclusions. The results for POLDIS are very similar to the ones for MEXDIS: the same two models fit the data well, with strong evidence of unit root in the first sub-period (before the crisis) and evidence of a possible stationary negative trend after December 1994. The fact that these two series behave in this similar way is in itself a result. However, in our opinion the unit root hypothesis is better supported by the evidence. The two main reasons are the following.

First, under the assumption of no drift and no trend, which seems reasonable for the risk premium, the hypothesis of unit root cannot be rejected on the whole sample and on the two sub-samples as well for both MEXDIS and POLDIS. Under the assumption of drift and trend, the fit is good on the complete sample; but for both MEXDIS and POLDIS in the first sub-period the drift and the trend are not significant and the null of unit root cannot be rejected. This is a strong evidence in favor of the hypothesis of unit root.

Second, the trend stationary model is very dependent on the date on which we decide there is a change in the constant (i.e. after which date the dummy begins to have value 1). The 16 of December 1994 is a reasonable choice, but we could make other choices as well (e.g. for Poland a reasonable choice could be the date in which the country received investment grade rating). There is no evidence of a structural break in data generating process on the 16 of December 1994 and so the dummy $d l$ is not needed. The dummy $d l$ is simply capturing the effect of a shock bigger than others, which - as the others - has a permanent effect.

Our interpretation of the unit root evidence is the following: traders update their priors on the default probability as new information accrues, and the new information can be interpreted as the shock. For the variable POLDIS we cannot reject the hypothesis of a random walk, that is a process in which the error term is a white noise. For MEXDIS we find an AR(4) with unit root, which means that the news have a permanent effect (with a lag of four weeks) and that the process has memory: the value of the risk premium at time $t$ depends on four lags of itself and on a white noise residual.

Is this interpretation of POLDIS and MEXDIS consistent with the evidence of a possible negative trend after December 94? Is this just the consequence of a sequence of good shocks after a big bad one, or it is a process showing mean reversion from a high level of the risk premium? It is evident that, while in principle the risk premium can go to infinitum ${ }^{18}$, it is in effect bounded from above. A very high risk premium (like the almost 2000 basis point on the Mexican bonds in December 1994) is not sustainable even in the very short term: a country in a period of crisis - like Mexico in December 1994 - can either go on default (which corresponds to an infinite risk premium) or be rescued by an international support package. This is why we find possible evidence of mean

\footnotetext{
${ }^{18}$ This implicitly happened on December 27 1994, when the Tesobono auction was canceled because the risk premium asked by the investors was not acceptable to the Mexican authorities.
} 
reversion after the Mexican crisis. But when we are not close to this threshold level, the behavior of the risk premium is very much like a random walk.

In conclusion, we find the unit root model for the stripped spread more consistent with the data, as argued above. The results are consistent also with our opinion that a proper model for the risk premium cannot have a drift and/or a trend, which would imply a divergent behavior in the long run. The autoregressive model without dummy gives a way to model all the variables in a symmetric way, without relying on our discretion to decide which shock can be thought as a change in the mean of an otherwise stationary process.

\subsection{Comovement analysis}

The main finding of the previous section is that we cannot reject the null of one unit root on MEXDIS and POLDIS. With non stationary time series the standard asymptotic theory does not hold and OLS estimates can be misleading. Engle and Granger (1987) introduced the concept of cointegration: a group of non-stationary time series is cointegrated if there is a linear combination of them that is stationary; the parameters of the linear combination are called the cointegrating vector. If two or more variables are cointegrated, the cointegrating vector can be "superconsistently" estimated by OLS. Usually the cointegrating equation is interpreted as a long run equilibrium relationship.

A very useful way to understand cointegration relationships is the Stock and Watson's (1988) observation that cointegrated variables share common stochastic trends (i.e. random walk components). A unit root process can be decomposed into a random walk plus a stationary (but not necessarily white noise) component. Hence, a linear combination of two non-stationary variables is stationary if and only if the random walk components are the same (up to a multiplicative scalar) for both variables. Therefore, we interpret cointegration not only as a "measure" for comovements, but also as a test for the hypothesis that different variables share the same innovation (random walk) process.

To begin our analysis on the comovements of MEXDIS and POLDIS, let us consider figure 7, which plots the difference (DIFF) between the two variables MEXDIS and POLDIS. The variable DIFF looks stationary with a shift in the mean from -200 bs.pts. to +350 bs.pts. after the Mexican crisis of December 1994. A preliminary estimate of the cointegration relationship is obtained regressing MEXDIS on: a constant, POLDIS and the dummy $d 2$ (dummy with ones after 1/20/95, i.e. after the US support package was announced on 1/12/95): 


\begin{tabular}{|lccccc|}
\hline LS // Dependent Variable is MEXDIS & & & & \\
Sample: $7 / 29 / 94-7 / 12 / 96$ & & & & \\
Included observations: 103 & & & & & \\
& & & & & \\
Variable & Coefficient & Std. Error & T-Statistic & Prob. \\
\hline C & -207.4990 & 49.24584 & -4.213533 & 0.0001 \\
D2 & 554.0909 & 28.96765 & 19.12792 & 0.0000 \\
POLDIS & 1.080204 & 0.067715 & 15.95221 & 0.0000 \\
& & & & & \\
R-squared & 0.834172 & Mean dependent var & 809.9767 \\
Adjusted R-squared & 0.830855 & S.D. dependent var & 297.5443 \\
S.E. of regression & 122.3717 & Akaike info criterion & 9.642820 \\
Sum squared resid & 1497483. & Schwartz criterion & 9.719560 \\
Log likelihood & -639.7559 & F-statistic & 251.5167 \\
Durbin-Watson stat & 0.451944 & Prob(F-statistic) & 0.000000 \\
& & & & & \\
\hline
\end{tabular}

All variables are very significant and the estimated coefficient of $d 2,550$, shows the dramatic change in the mean of the relation after $1 / 20 / 95$. Thus, we generated the variables MEXDIS $1=M E X D I S-550^{*} d 2$ and DIFF1=MEXDIS 1 POLDIS to perform tests of cointegration. The idea is that, except for a change in the mean of the relation, the two variables are cointegrated, i.e. have the same random walk component. As we will discuss in section 5 , the change in the mean of the relation can be interpreted as the change in the relation between Mexico's and Poland's fundamentals induced by the Mexican crisis.

To test properly for cointegration, we consider the following Error Correction Model (ECM) ${ }^{19}$ :

$$
\begin{aligned}
& \triangle M E X D I S 1_{t}=\alpha_{M}\left(c+\text { MEXDIS }_{t-1}+\beta \text { POLDIS }_{t-1}\right)+\delta_{M} \Delta M E X D I S 1_{t-1}+\gamma_{M} \Delta P O L D I S_{t-1}+\varepsilon_{M t} \\
& \triangle P O L D I S_{t}=\alpha_{P}\left(c+M E X D I S 1_{t-1}+\beta \text { POLDIS }_{t-1}\right)+\delta_{p} \Delta M E X D I S 1_{t-1}+\gamma_{P} \Delta P O L D I S_{t-1}+\varepsilon_{P t}
\end{aligned}
$$

\footnotetext{
${ }^{19}$ In order to test for cointegration and to have a proper estimate of the cointegration vector we have to specify an error-correction model (ECM). This is because cointegration tests are usually performed on the error-correction representation. Note that, if two or more variables are cointegrated, it is guaranteed that an error-correction model representation exists. This is the so called Granger representation theorem: for any set of $I(I)$ variables, cointegration and error-correction are equivalent representations. Moreover, the most common procedure to test for the lag length is to estimate a Vector Auto Regression (VAR) using data in levels. We consider VARs with 2 or more lags: the VAR with one lag presents evidence of autocorrelation in the. The Akaike Information Criterion suggests a specification with 2 lags and the Chi test suggested by Sims (1980) does not reject the null of a lag length of 2 versus 3 or more lags.
} 


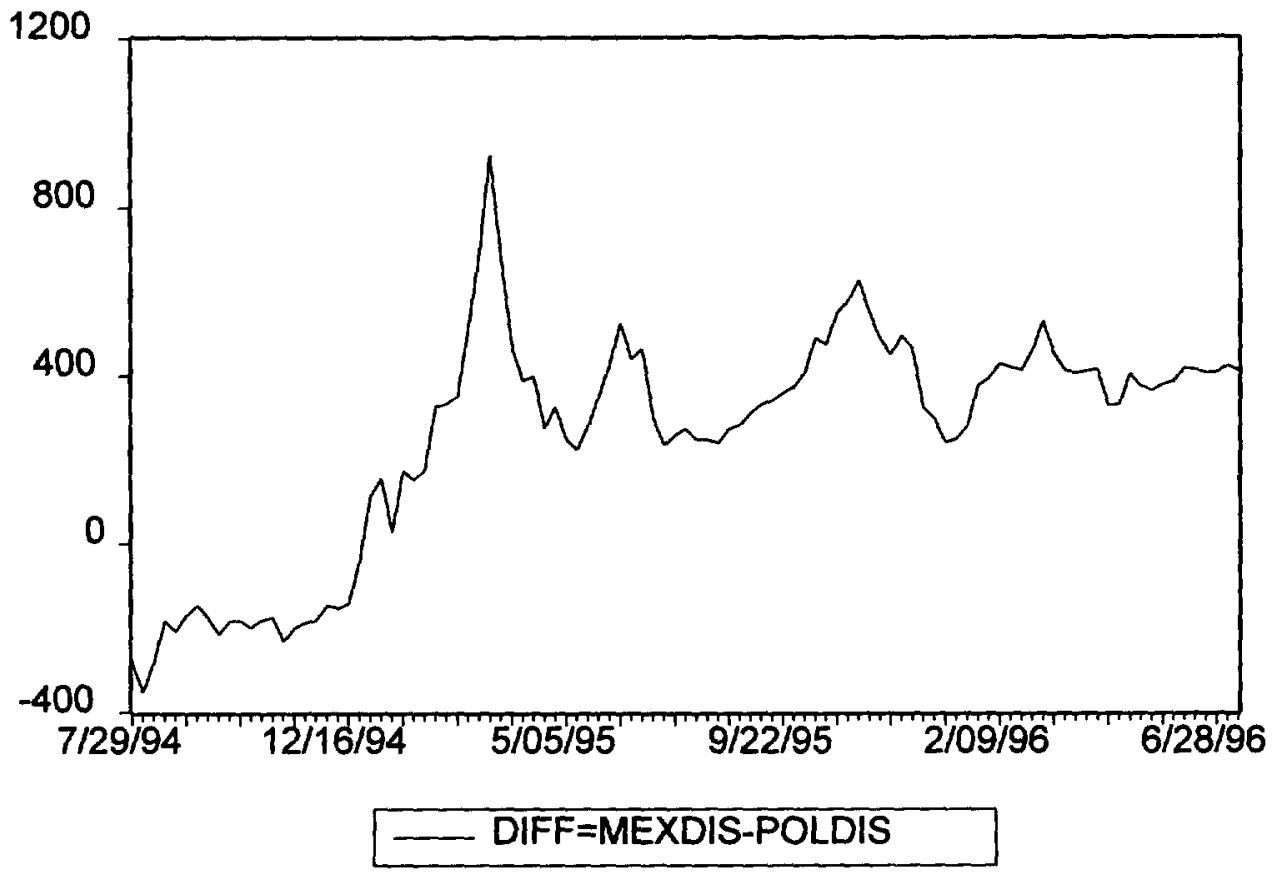

Figure 7

The Johansen Cointegration Test is reported below:

Sample: $7 / 29 / 94-7 / 12 / 96$

Included observations: 101

Test assumption: No deterministic trend in the data

Series: MEXDISI POLDIS

Lags interval: 1 to 1

$\begin{array}{lllll}\text { Ejgenvalue } & \begin{array}{l}\text { Likelihood } \\ \text { Ratio }\end{array} & \begin{array}{l}\text { 5 Percent } \\ \text { Critical Value }\end{array} & \begin{array}{l}\text { 1 Percent } \\ \text { Critical Value }\end{array} & \begin{array}{l}\text { Hypothesized } \\ \text { No. of CE(s) }\end{array} \\ 0.259056 & 32.22498 & 19.96 & 24.60 & \text { None } \\ 0.019045 & 1.942089 & 9.24 & 12.97 & \text { At most 1 }\end{array}$

L.R. test indicates 1 cointegrating equation(s) at $5 \%$ significance level

Unnormalized Cointegrating Coefficients:

$\begin{array}{cll}\text { MEXDIS1 } & \text { POLDIS } & \text { C } \\ 0.000880 & -0.000924 & 0.152483 \\ -5.53 E-05 & -0.000259 & 0.084977\end{array}$

Normalized Cointegrating Coefficients: 1 Cointegrating Equation(s)

$\begin{array}{cll}\text { MEXDIS1 } & \text { POLDIS } & \text { C } \\ 1.000000 & -1.050131 & 173.3165 \\ & (0.10657) & (62.6566)\end{array}$

(Log likelihood -1273.927) 
The cointegration hypothesis is not rejected even at $1 \%$ critical level. ${ }^{20}$ Moreover, we cannot reject the null that the (normalized) cointegration vector is $(1,-1)$, which implies that the series have exactly the same random walk (stochastic trend) component.

Next, we split the sample (two years from 7/29/94 to 7/12/96) in two: the first sub-sample goes from 7/29/94 to $7 / 28 / 95$ (51 observations) and includes the period of the Mexican crisis; the second one goes from 7/28/95 to $7 / 12 / 96$ ( 51 observations). We report below the results for the cointegration tests on the two sub-samples.

1) First sub-period (7/29/94 to 7/28/95):

Sample: $7 / 29 / 94-7 / 28 / 95$

Included observations: $5 I$

Test assumption: No deterministic trend in the data

Series: MEXDISI POLDIS

Lags interval: 1 to $l$

$\begin{array}{lllll}\text { Eigenvalue } & \begin{array}{l}\text { Likelihood } \\ \text { Ratio }\end{array} & \begin{array}{l}\text { 5 Percent } \\ \text { Critical Value }\end{array} & \begin{array}{l}\text { 1 Percent } \\ \text { Critical Value }\end{array} & \begin{array}{l}\text { Hypothesized } \\ \text { No. of CE(s) }\end{array} \\ 0.343390 & 24.04490 & 19.96 & 24.60 & \text { None } \\ 0.049535 & 2.590984 & 9.24 & 12.97 & \text { At most 1 }\end{array}$

\section{L.R. test indicates 1 cointegrating equation(s) at $5 \%$ significance level}

Unnormalized Cointegrating Coefficients:

$\begin{array}{ccc}\text { MEXDIS1 } & \text { POLDIS } & \text { C } \\ 0.001156 & -0.001715 & 0.561364 \\ -1.78 \mathrm{E}-05 & 0.001175 & -0.757838\end{array}$

Normalized Cointegrating Coefficients: 1 Cointegrating Equation(s)

$\begin{array}{ccl}\text { MEXDIS1 } & \text { POLDIS } & \text { C } \\ 1.000000 & -1.483337 & 485.6730 \\ & (0.19940) & (138.440)\end{array}$

(Log likelihood -628.7797)

\footnotetext{
${ }^{20}$ Note that we performed the tests for the lag length on a VAR in levels. The ECM is specified in first differences, so the lag length should be reduced by one.
} 
2) Second sub-period (7/28/95 to 7/12/96):

Sample: 7/28/95 - 7/12/96

Included observations: 51

Test assumption: No deterministic trend in the data

Series: MEXDIS1 POLDIS

Lags interval: 1 to 1

$\begin{array}{lllll}\text { Eigenvalue } & \begin{array}{l}\text { Likelihood } \\ \text { Ratio }\end{array} & \begin{array}{l}5 \text { Percent } \\ \text { Critical Value }\end{array} & \begin{array}{l}1 \text { Percent } \\ \text { Critical Value }\end{array} & \begin{array}{l}\text { Hypothesized } \\ \text { No. of CE(s) }\end{array} \\ 0.185747 & 11.99515 & 19.96 & 24.60 & \text { None } \\ 0.029278 & 1.515477 & 9.24 & 12.97 & \text { At most 1 }\end{array}$

\section{L.R. rejects any cointegration at $5 \%$ significance level}

Unnormalized Cointegrating Coefficients:

\begin{tabular}{ccl} 
MEXDIS1 & POLDIS & \multicolumn{1}{l}{ C } \\
0.001493 & -0.001499 & 0.176611 \\
-0.000671 & $7.73 E-05$ & 0.044013
\end{tabular}

Normalized Cointegrating Coefficients: 1 Cointegrating Equation(s)

$\begin{array}{ccl}\text { MEXDIS1 } & \text { POLDIS } & \text { C } \\ 1.000000 & -1.003506 & 118.2626 \\ & (0.20818) & (93.4870)\end{array}$

(Log likelihood -558.2001)

The null hypothesis of cointegration is not rejected in the first sub-sample, but it is rejected on the second one. Note also that, for the first sub-sample, the estimated coefficient on POLDIS is significantly greater than one. ${ }^{21}$

We can reach two main conclusions from these results:

1) First, comovements were stronger during the high volatility period of the Mexican crisis. In fact, we reject the null hypothesis of cointegration for the last year, when the crisis was perceived as overcome.

2) Second, the Mexican crisis has caused a change in the mean of the cointegration relation of approximately 550 bs.pts.. That is, the crisis has had a strong permanent effect on the risk assessment on Mexico.

\footnotetext{
${ }^{21}$ To confirm the results, we perform the cointegration test on the original variable MEXDIS (instead of MEXDIS1). The results of the cointegration tests for the two sub-periods - from 1/20/95 to 7/12/96 (78 observations), and from 7/28/95 to 7/12/96 (51 observations) confirm that there is strong evidence of cointegration on the whole sample, while the variables are not cointegrated for the period $7 / 29 / 94$ to $7 / 12 / 96$ (the last year).
} 
We study next the properties of the ECM on different sample periods in order to answer the following questions: Can we quantify the response of POLDIS to a shock to MEXDIS? To which extent the volatility of POLDIS is due to the volatility of MEXDIS?

These questions can be answered through what is generally referred to as innovation accounting, i.e. the impulse response function and the forecast error variance decomposition. The impulse response function uses the estimated parameters of the model to trace out the effects of one standard deviation (SD) change in the errors on the time path of MEXDIS and POLDIS sequences; the forecast error variance decomposition uses the estimated parameters and indicates the proportion of the forecast errors on a variable which is due to its own shocks (residuals) as opposed to shocks (residuals) to the other variable. ${ }^{22}$

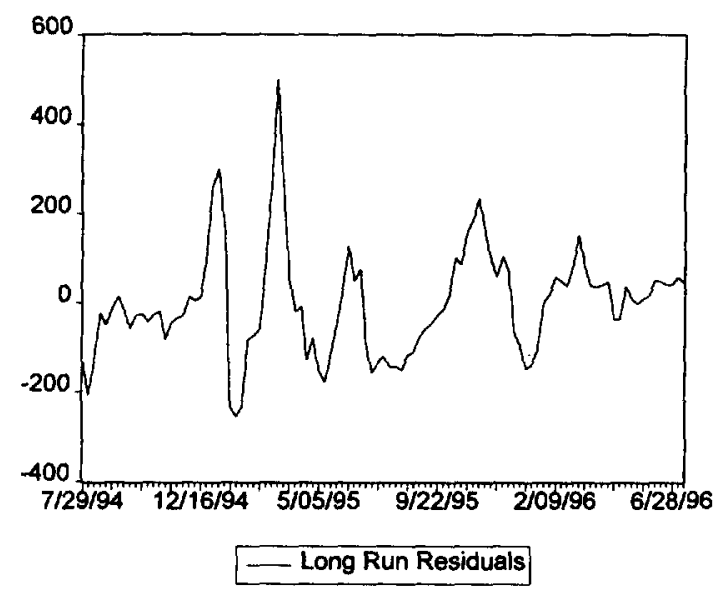

Figure 8

The impulse response function in figure 9 shows that: 1) a one standard deviation innovation to MEXDIS1 (the SD of the residuals on MEXDIS 1 being of 91 bs. pts.) has a permanent effect of $36 \mathrm{bs}$. pts on MEXDIS1 and of $35 \mathrm{bs}$. pts. on POLDIS; 2) a one standard deviation innovation to POLDIS (the SD of the residuals on POLDIS being of 44 bs. pts.) has a permanent effect of $29 \mathrm{bs}$. pts. on MEXDIS1 and of $27 \mathrm{bs}$. pts. on POLDIS. We can conclude that a

\footnotetext{
${ }^{22}$ The only problem with this methodology is that an estimated VAR is underidentified: an additional restriction must be imposed on the two variable VAR system in order to identify the impulse responses and variance decomposition. The usual restriction is given by the assumption that one error has a contemporaneous effect on both variables, while the other one has a contemporaneous effect only on its own variable. This assumption is said to imply an ordering of the variables.

We assume that $\varepsilon_{M t}$ has a contemporaneous effect on both variables, while $\varepsilon_{p t}$ does not. This is not an innocuous assumption: the correlation coefficient on the estimated residuals is above 0.7 , so the ordering matters. Our assumption is based on several considerations. The first one is that, at least for the first year of our sample (when the evidence of cointegration is stronger), all the relevant volatility was coming from the news on Mexico and not on Poland. Second, we regressed the residuals from the cointegration relation (the "long run" residuals, LRER in figure 8) on the standard deviation of MEXDIS (MSIG) and on the standard deviation of POLDIS (PSIG): not only MSIG is more significant than PSIG and with the right sign, but the negative sign of PSIG suggests that the volatility of MEXDIS dominates. Finally, and consistently with our belief that Mexico is a leader in the Brady market, the IMF (1995) finds evidence of Granger causality from Mexico to other countries using daily bond prices.
} 
shock to MEXDIS1 has a stronger permanent effect on both variables than a shock to POLDIS (even though the residuals on MEXDIS1 are more volatile).

From the analysis of the impulse response function we can reach another important conclusion: on the basis of the estimated coefficients of the Vector Error Correction model, a one standard deviation innovation to MEXDIS has a permanent effect on POLDIS of 35 bs. pts. (out of 91 bs. pts.) or of 44 bs. pts. (out of 118 bs. pts.) depending on the sample period - in both cases $38 \%$ of a shock to MEXDIS has a permanent effect on POLDIS.

\section{Response to One S.D. Innovations}
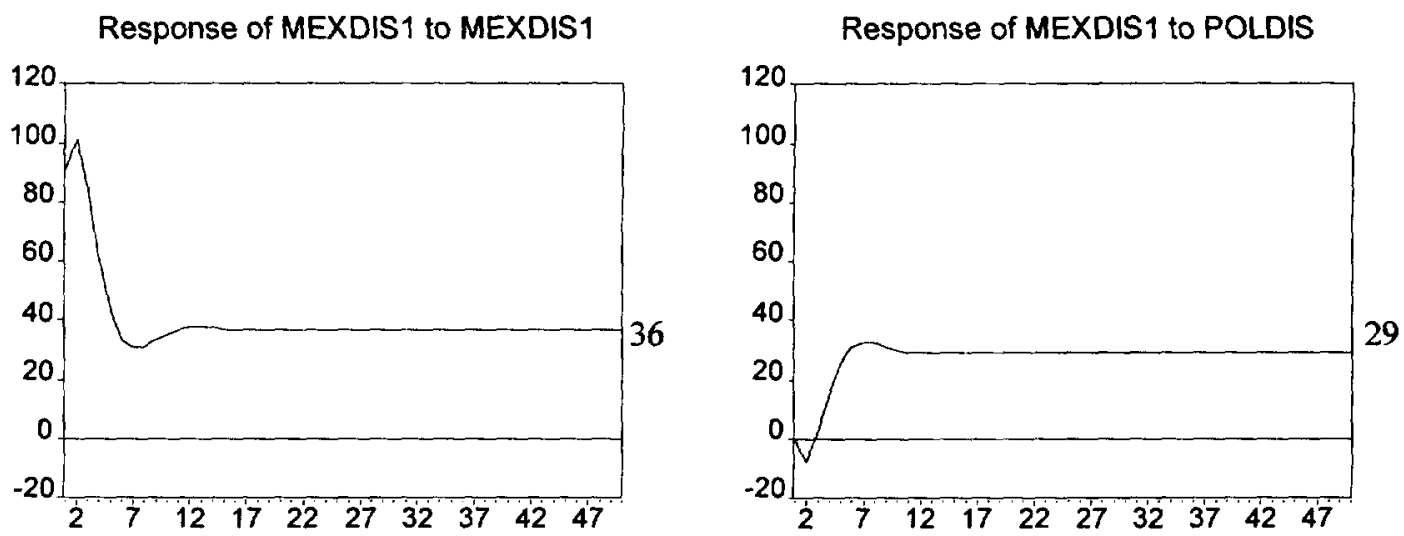

Response of POLDIS to MEXDIS1

Response of POLDIS to POLDIS
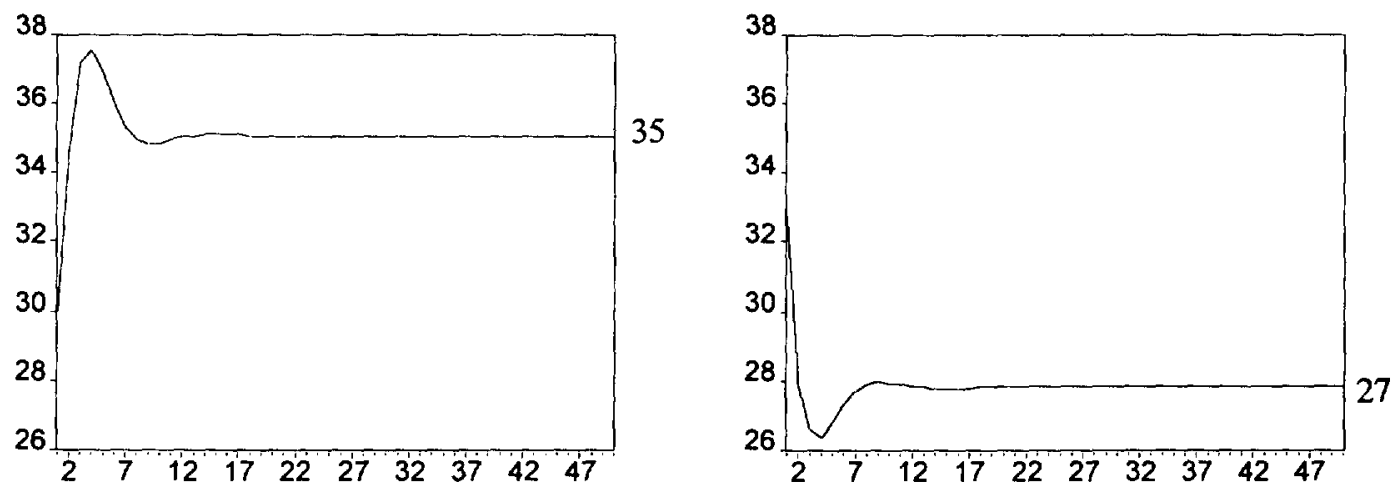

Figure 9

The forecast error variance decomposition reported in figure 10 shows that: 1) the long run forecast error on MEXDIS1 is due for $70 \%$ to innovations to MEXDIS1 and for $30 \%$ to innovations to POLDIS; 2 ) the long run forecast error on POLDIS is due for $61 \%$ to innovations to MEXDIS1 and for the remaining $39 \%$ to innovations to 
POLDIS. We note a significant asymmetry in the behavior of the two variables, with $61 \%$ of the variability of POLDIS coming from the variability of MEXDIS $1 .^{23}$

\section{Variance Decomposition}
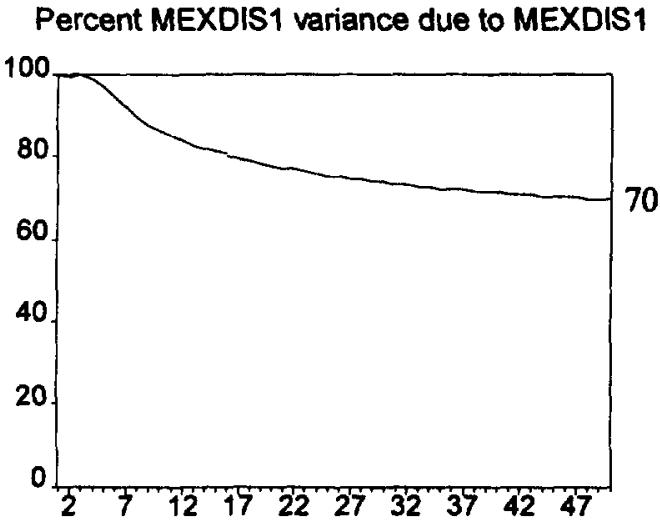

Percent POLDIS variance due to MEXDIS1

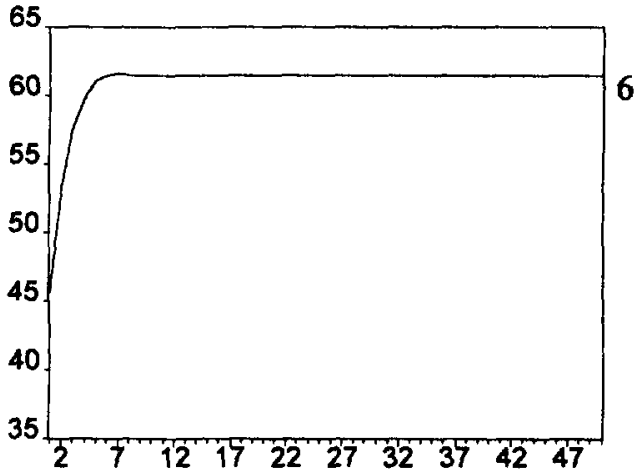

Percent MEXDIS1 variance due to POLDIS

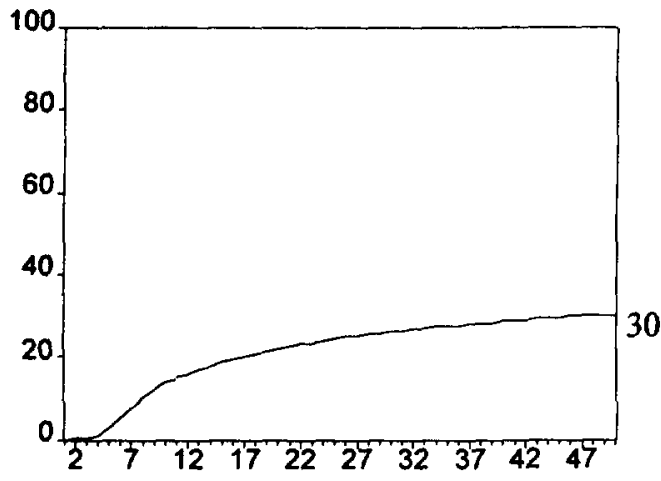

Percent POLDIS variance due to POLDIS

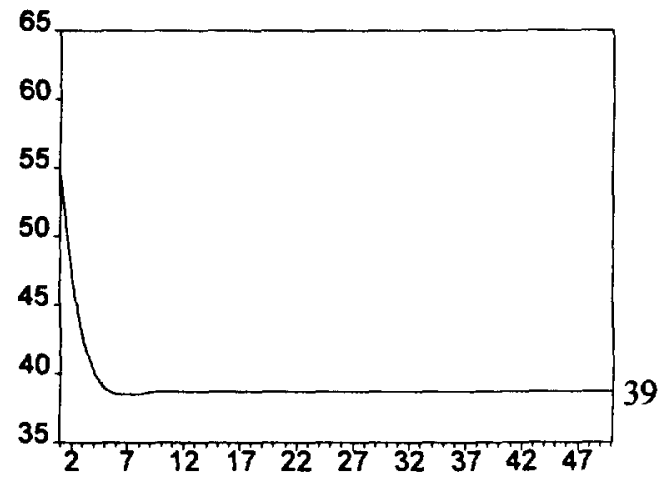

Figure 10

In the following section we present our interpretation of the empirical evidence reported so far. In particular, we introduce learning spillovers as a potential explanation of the link between the sovereign risk premia of different countries. But at this stage we also want to stress how strong these links are: on the basis of our estimates, $38 \%$ of a shock to MEXDIS has a permanent effect on POLDIS; in section 6 we will report that the volatility increased for most bonds two to four times after the Mexican crisis. Therefore, in what follows, we maintain the implicit assumption that learning spillover effects cannot by itself explain such excessive responses.

\footnotetext{
${ }^{23}$ We have estimated the ECM for MEXDISI and POLDIS on the period 7/29/94 to 7/28/95, i.e. the period comprising the Mexican crisis and during which the comovements are stronger. The results are confirmed: in particular, the variability of POLDIS is now even more dependent on the variability of MEXDIS1 (68\% versus $61 \%$ ) and the amount of the permanent effect on MEXDISI due to innovations on both variables has increased relative to the increase in the standard deviations of the residuals (the permanent relative response to MEXDIS1 innovations has shifted from 0.4 to 0.55 , whereas the permanent relative response to POLDIS innovations has shifted from 0.66 to 0.82 ). Finally, the ECM estimates for MEXDIS (instead of MEXDIS1) and POLDIS for the sample 1/20/95-7/12/96 are substantially the same.
} 


\section{What causes the spillover effect?}

It is reasonable to assume that traders' investment decisions are based essentially on two elements: their private information on fundamentals; and the behavior of other traders. The private information on fundamentals provides traders with a belief on the probability of default of a debtor country. The behavior of other traders is important not only because it conveys some additional information, but also because traders' reputations (in the labor market) are based both on their success in terms of profitable investments and on whether their decisions were similar to or different from those of other traders. ${ }^{24}$ In this section we argue that this two elements can explain spillover effects. 25

Private information on fundamentals is the leading force behind an investment decision and assume that news on a particular developing country conveys some information on other developing countries. ${ }^{26}$ This could be due, for example, to the fact that different countries are applying reform programs - like Brady plans - that are perceived as similar. Thus, the Mexican crisis can be a signal that the Brady plan on Mexico is not feasible or that the Mexican government finds the commitment to the plan not rewarding enough. Therefore, we might think that also the Brady plan for Poland is not feasible or that Polish government may not have enough incentive to abide to the Brady plan.

At this point an important aside is in order to understand why we introduce the hypothesis of learning spillover and do not consider the possibility that comovements were due simply to similar movements in fundamentals. Assume that the probability of default $(1-\pi)$ is a function of fundamentals "observable" $Z_{o b s}$ (as budget deficit, exchange rate, etc.) and fundamentals "not-observable" $Z_{\text {not -obs }}$ (as the government commitment to the reform program or the feasibility of the program itself), that is: $(1-\pi)=f\left(Z_{o b s}, Z_{\text {not-obs }}\right)$. The Mexican crisis has substantially changed $Z_{o b s}$ for Mexico, but not for other countries as Poland. Therefore, the jump in the probability of default and thus in the risk premium cannot be due to a change in $Z_{\text {obs }}$ for the Brady countries other than Mexico; it has to come from the change in $Z_{m o t-o b s}$. This effect trough $Z_{\text {mot-obs }}$ is what we define as learning spillover.

The interesting point in analyzing the period of the Mexican crisis is that we can assume $Z_{\text {obs }}$ didn't change for all countries except Mexico and it cannot be argued that comovements were due to a similar change in observable fundamentals. As an example on Mexico and Poland, let's consider the exchange rate: the Polish currency (the

\footnotetext{
24 Scharfstein and Stein (1990) argue that "Under certain circumstances, (fund) managers simply mimic the investment decisions of others managers, ignoring substantive private information. Although this behavior is inefficient from a social standpoint, it can be rational from the perspective of managers who are concerned about their reputation in the labor market."

${ }^{25}$ It is our opinion that the explanations of spillover effects in the Brady bond market based on trade agreements or technological spillovers can not account for the very short period spillovers of the Brady bond market.

Institutional factors concerning the structure of big funds could be another explanation. An emerging market fund, for instance, could expect a higher amount of redemptions following a large adverse shock (as the Mexican crisis) and could sell off assets in several emerging market to generate cash. This story, though, does not explain why the fund manager should prefer to sell off the assets instead of rising cash trough borrowing.

${ }^{26}$ The information available on a country and the experience in that country's market are usually much less for developing and middle income countries than for industrialized ones. In our opinion this is the reason why spillover effects are not relevant for developed countries.
} 
zloty) appreciated in real terms during the Spring of 1995. Moreover, the change in the mean of the cointegrating relation between Mexico and Poland discussed in section 4 is consistent with the hypothesis that the Mexican crisis changed the relation between the fundamentals of Mexico and Poland. Finally, the fact that the null of cointegration for the second year of our sample (July 95-July 96) is rejected proves that comovements during the Mexican crisis were not due to similar fundamentals.

The behavior of other traders is another leading force in investment decisions. Scharfstein and Stein (1990) argue that this is the case because traders are concerned about their reputation in the labor market. If a trader decides to 'go against' the market, his or her reputation is much more damaged by under-performing than it is strengthened by over-performing: “...smart managers tend to receive correlated signals (since they are all observing a piece of the same "truth"), while dumb ones do not (they simply observe uncorrelated noise). Consequently, if one manager mimics the behovior of others, this suggests to the labor market that he has received a signal that is correlated with theirs, and is more likely to be smart. In contrast, a manager who takes a contrarian position is perceived as more likely to be dumb, all else being equal. "27 Thus traders face an asymmetry in investment decisions which leads them to follow the herd.

Note that herd behavior is an explanation for excess price volatility: "By mimicking the behavior of others (i.e., buying when others are buying, and selling when others are selling) rather than responding to their private information, members of a herd will tend to amplify exogenous stock price shocks. "28 But herd behavior is not by itself an explanation of spillover effects. Herd behavior implies that traders tend to hold the same portfolio and tend to follow the same asset allocation strategy, but does not explain which this portfolio or asset composition is. In particular, it does not explain why a shock on Mexico should lead to a reduction of the exposure on Poland.

It is our opinion that learning spillovers and herd behovior are complementary in the explanation of spillover effects: a negative shock can be a source of spillover effects and also cause an increase in traders' expected volatility; higher expected volatility leads to herd behavior, which in turn amplifies the original spillover effects and increases actual volatility.

Why should a negative shock increase traders' expected volatility? To understand this point define (1- $\pi)$ the probability of default and consider an asset that has zero return in case of default and has $x$ as return in case of no default; the variance of this asset can be written as $x^{2}[\pi(1-\pi)$, which is a parabola with a maximum for $\pi=1 / 2{ }^{29}$ Therefore, a negative shock that shifts the probability of default toward middle values (for example from

\footnotetext{
${ }^{27}$ Scharfstein and Stein (1990), page 466.

${ }^{28}$ Scharfstein and Stein (1990), page 477.

${ }^{29}$ The assumption of two possible outcomes(default or not) is simplifying but not simplistic. The general case would be to consider the entire distribution of returns. This distribution, though, would have two mass points: one at the return in case of no default and one at the expected return given the default. So we would have a bimodal distribution.
} 
.1 to .3 , i.e. closer to the value $\pi=1 / 2$ for which the expected volatility is at the maximum) ${ }^{30}$ causes an increase in the expected volatility of returns.

Higher expected volatility means that traders are more uncertain on bonds' return and face the possibility of big losses: uncertainty on returns and possibility of big losses increase herd behavior and actual volatility. Therefore, actual volatility is an increasing and monotone function of expected volatility and it can be represented as $\sigma(\pi)$ in figure 11 .

The fact that comovements of the risk premium were stronger during the high volatility period of the Mexican crisis is consistent with the idea that during periods of high uncertainty (defined as periods when the probability of default move towards $1 / 2$ - and news have a very informative content, i.e. lead to a relevant update of the prior belief - so that the expected volatility of returns is high) herd behavior is stronger than during periods of relative calm (defined a periods during which the probability of default is close to the extremes - and news do not have a very informative content, i.e. do not lead to a relevant update of the prior belief - so that the expected volatility of returns is low).

However, another element could lead to excess volatility. We know that the risk premium reflects mainly the probability of default of a sovereign country. A negative shock which substantially shifts the probability of default towards middle values, will lead to lower prices and also increase the expected volatility of returns. Risk averse agents will require a premium for this increase in the expected volatility of returns, and the price of the bond will further decrease. Thus, if agents are risk averse, a bad news will depress prices more than the expected value of returns, thereby increasing the actual volatility of the risk premium.

Both herd behavior and risk aversion lead to excess volatility in response to a negative shock. Which of the two is more relevant is an empirical question. Our belief is that the risk (aversion) premium cannot account for increases in volatility of 100 to 200 bs. pts. as we observed during the Mexican crisis. For our purposes it is important that both mechanisms lead to excess volatility following a negative shock that moves the probability of default toward $1 / 2$, thus amplifying the 'spillover effects'. Moreover, both mechanisms imply that expected volatility and actual volatility are positively correlated and that both reach a maximum for values of the probability of default close to 1/2. Figure 11 summarizes our argument. It represents also the mean of the risk premium $\mu$ as a function of the probability of default ( $1-\pi$ ), which is convex for the following reason: define the risk premium as $R P$ and $r$ the US interest rate; arbitrage condition implies that $(1-\pi) 0+\pi(R P+r)=r$, from which $R P=(r / \pi)-r$. Note also that $R P=0$ when $\pi=1$.

\footnotetext{
${ }^{30}$ Cumby and Evans (1993) estimate a probability of default well below $10 \%$ for Mexico and Venezuela (below $15 \%$ for Costa Rica) over the period 12/90-12/92. Thus it seems appropriate to assume in our arguments that the probability of default was, before the crisis, close to the lower bound of 0 .
} 


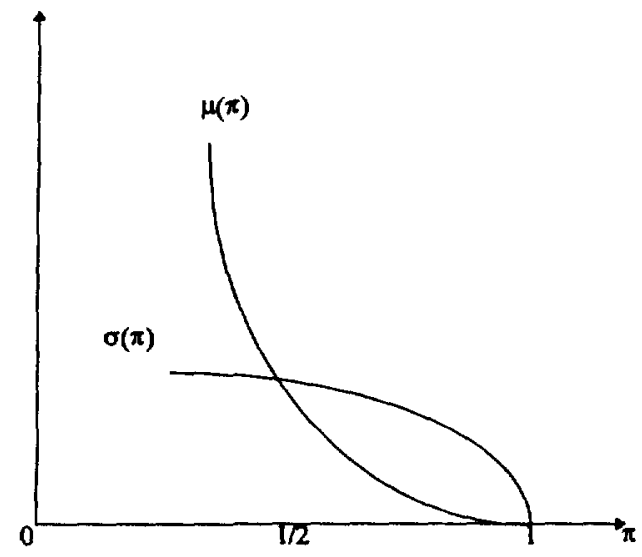

Figure 11

From figure 11 we can derive three important implications which will be tested in the next section:

1) first, the concavity of the volatility with respect to the probability of default implies that, during periods of crisis in which the probability of default for all countries moves towards $1 / 2$, we should observe a convergence in the levels of volatility: countries with low volatility - low probability of default - should have an absolute and relative increase in volatility higher than countries with high volatility - probability of default close to $1 / 2$.

2) second, the mean and the volatility of the risk premium should have a positive (and concave) relation on the relevant range (the relevant range is for the probability of default between zero and 1/2).

3) third, the volatility should be concave when plotted against the probability of default.

Finally, we have found no evidence of comovements in the aftermath of the Mexican crisis, which can be considered a period of relative calm. In fact, in periods of relative calm there is not much room for learning spillovers and, even if there is herd behavior on single assets, this cannot by itself cause co-movements.

\section{How did other countries respond to the crisis?}

In this section we will test our interpretation on the bonds of the other countries in our sample: Argentina, Brazil, Ecuador, Venezuela, Bulgaria, Nigeria, Philippines. We will not perform cointegration tests for all countries and for different periods. The case of Mexico and Poland has been informative enough on the unit root and cointegration hypothesis. In this section we will: 1) look at how the risk premium of the other countries in our sample responded to the Mexican crisis; 2) test, on a cross-country basis, the three implications we have derived from figure 11. 
1) Figures 12-15 report the plots of the risk premium for the South American countries and Nigeria on the period of the Mexican crisis $(7 / 29 / 94 \text { to } 7 / 28 / 95)^{31}$ : the plots show that all five countries had a significant response to the crisis. Moreover, NIGPAR is affected by the peaks of MEXPAR but it follows a much more volatile path, and it has a behavior very similar to VENPAR.

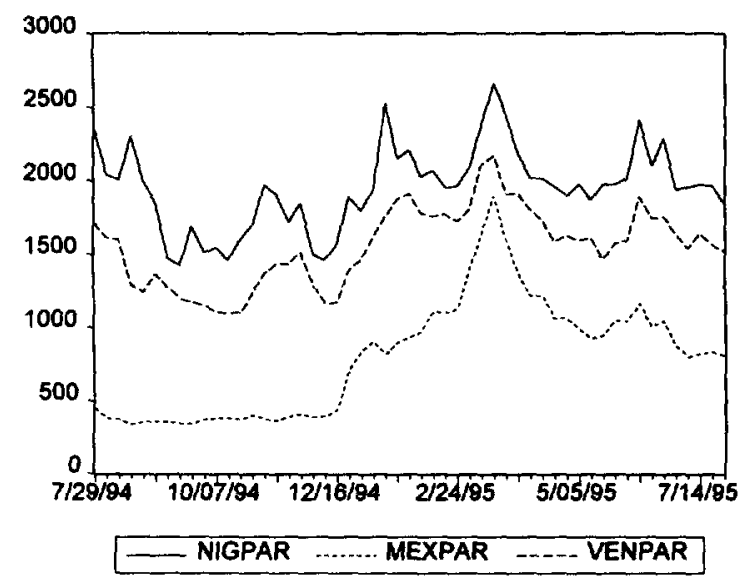

Figure 12

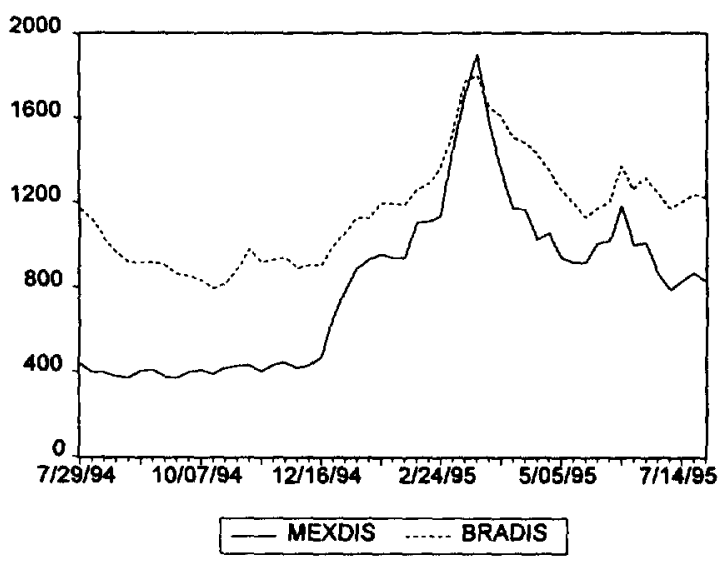

Figure 14

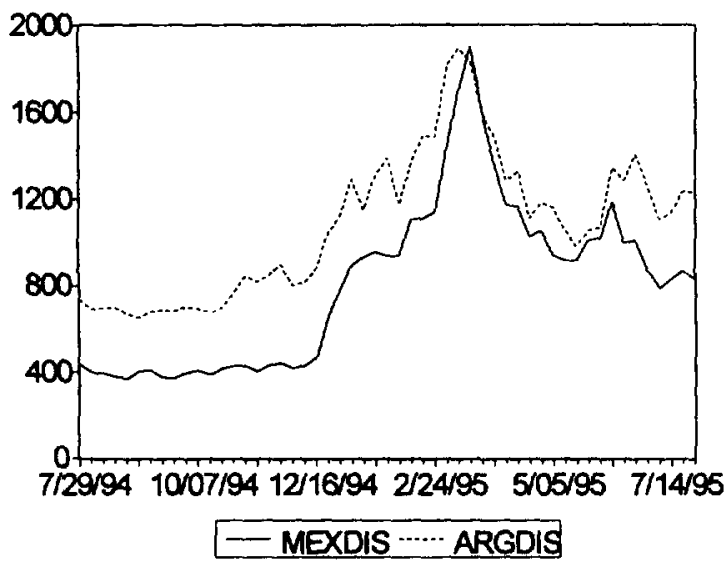

Figure 13

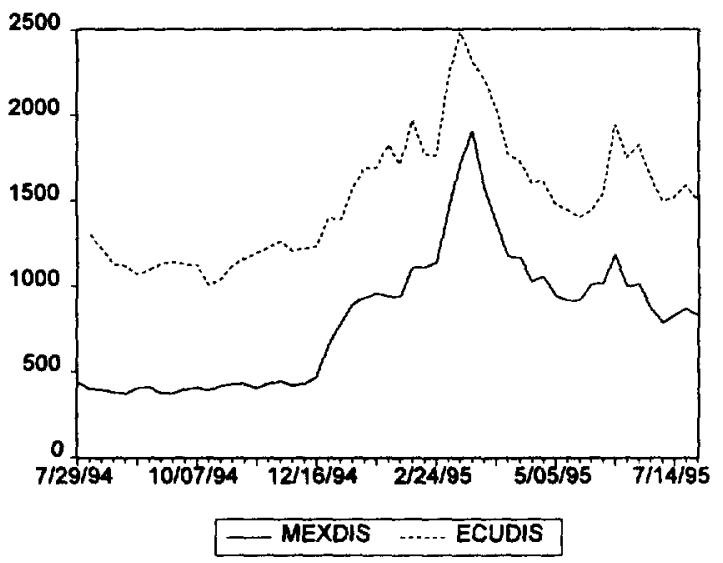

Figure 15

Consider now the other countries in our sample, Philippines and Bulgaria, in figure 16-18. Note how similar to Poland's is the behavior of the Philippines' bond: the difference between MEXPAR and PHIPAR (DIFF) shows the

\footnotetext{
${ }^{31}$ A first glance at the plots in figure 5 shows that there is no strong evidence of comovements in the risk premium except during periods in which one of the countries experiences a relevant crisis. We have divided the countries in groups on the basis of different factors to see if there was any evidence of comovements in the sub-groups. First, the oil producers: Mexico, Venezuela and Nigeria; while Venezuela and Nigeria move together during the Mexican crisis (7/29/94 to 7/28/95), on the whole sample the three series have a very different behavior. Second, the South American countries: Mexico, Brazil, Argentina, Ecuador and Venezuela; again, during the Mexican crisis the comovements are evident, but this is not the case for the whole sample. The same conclusion holds if we divide the countries on the basis of the date in which the Brady deal was announced or actually implemented.
} 
same shift in the mean of an otherwise stable relationship, as in the Poland case. On the other hand, BULDIS remains above MEXDIS (even if the distance between the two decreases) and follows a behavior similar to ECUDIS. $^{32}$

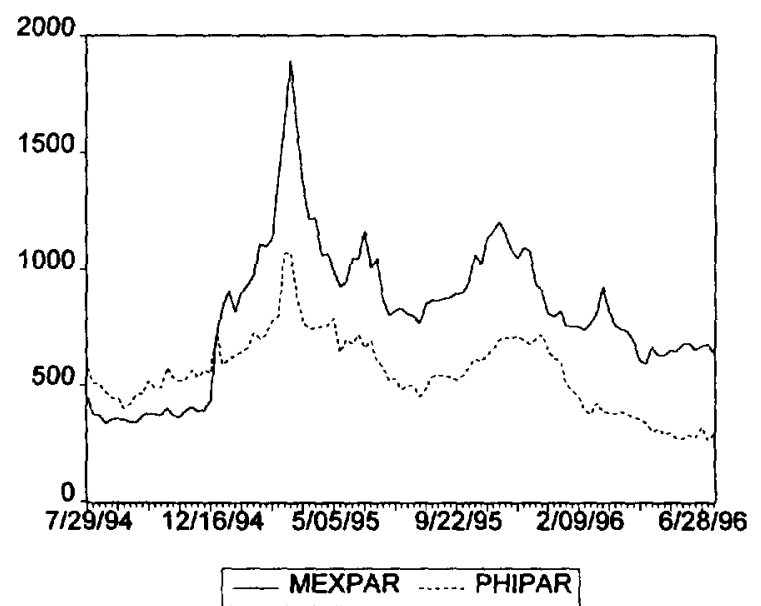

Figure 16

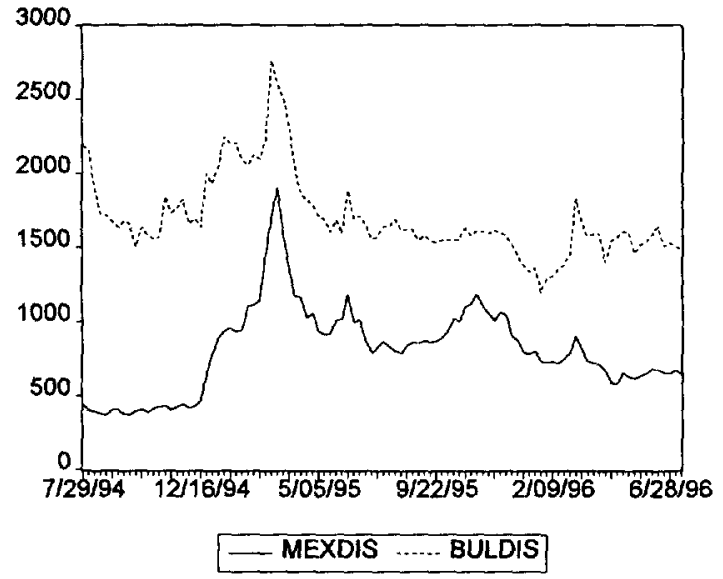

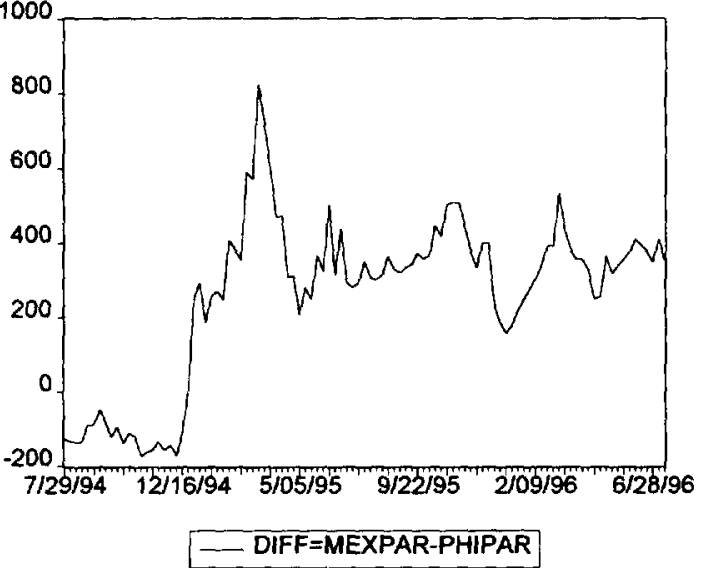

Figure 17

Figure 18

From this brief analysis we reach two conclusions:

i) there is evidence of comovements during the Mexican crisis (and for the Venezuelan crisis, even if in this case the evidence is less strong);

\footnotetext{
${ }^{32}$ We could do a similar exercise for the political crisis that hit Venezuela in $92 / 93$. A military coup failed in February 1992 and a second military coup was attempted in November 1992. The political crisis continued for the entire year 93 until the December 93 elections, but it was less acute after the summer when an interim government was appointed after the suspension from office of president Perez on May 20 . By January 92 the Brady bonds already issued were those of Nigeria and Mexico. The date of issue for Argentina was 4/93 and for Philippines was 12/92. Note that before January 92 the Venezuelan bonds were the less volatile and with the lowest mean among the Brady bonds. The data suggest that: NIGPAR reacted to the crisis in such a way that it is not easy to trace out comovements of the two variables; MEXDIS, which was a relatively stable title at the time, is only slightly affected by the crisis; on the other hand, the newly issued bonds of Argentina and Philippines show signs of comovements with VENDIS and VENPAR respectively.
} 
ii) different Brady bonds responded differently to the Mexican (and Venezuelan) crisis; countries with similar precrisis mean and volatility reacted in a similar way, in terms of both absolute deviation and degree of comovement with the Mexican bonds: low mean and volatility bonds (as Poland and Philippines) seem to have responded in a similar way to the crisis; similarly high mean and volatility bonds (Nigeria and Venezuela) or in-between bonds (as Brazil and Argentina, or Ecuador and Bulgaria). ${ }^{33}$

Given the interpretation we have presented in the previous section, the mean and the volatility of a bond are good proxies for the probability of default, which is the key element to determine how the risk premium will respond to a negative shock. In what follows we will test the three implications we have derived in the previous section.

2) To test the three implications we define a 'crisis' period and a 'pre-crisis' period. The 'pre-crisis' period goes from $8 / 05 / 94$ to $12 / 09 / 94$, the 'crisis' period from $12 / 16 / 94$ to $4 / 21 / 95 .{ }^{34}$ We then compute the volatility (standard deviation) of the risk premium for both the crisis and pre-crisis periods for all the bonds in our sample. The absolute increase in the volatility is given by the difference of the standard deviations on the two sub-periods, while the relative increase is given by the absolute increase divided by the standard deviation of the pre-crisis period.

i) To test the first implication we regress the absolute increase and relative increase on the standard deviation of the pre-crisis period. The result are plotted in figure 19 and 20 in terms of bs. pts.. The figures show that there is evidence of convergence of the volatility during the crisis, both in absolute and relative terms. The convergence of the volatility is another aspect of the 'pooling effect' during periods of high uncertainty.

\footnotetext{
${ }^{33}$ An important remark is in order here. We argue that countries with similar pre-crisis mean and volatility reacted in a similar way to the crisis. Now, consider the function $(1-\pi)=f\left(Z_{o b s}, Z_{n o t-o b s}\right)$ we introduced in section 5 . If we assume that the functional form $f($.) is the same for all countries, in absence of spillover effects through $Z_{\text {nof-obs }}$ (that is in the pre-crisis period, during which there were not major idiosyncratic shocks), countries with similar observable fundamentals should have had a similar probability of default (1- $\pi$ ) and thus similar risk premium mean and variance. Thus, to argue that the response to the crisis depended on the pre-crisis mean and volatility is equivalent to arguing that the response depended on pre-crisis (observable) fundamentals, as we should expect.

${ }^{34}$ The choice of these periods is somehow arbitrary. The four months period chosen reflects the fact that by April 95 the crisis was perceived as overcome. However, the results are substantially the same for different periods, as 3 or 6 months.
} 


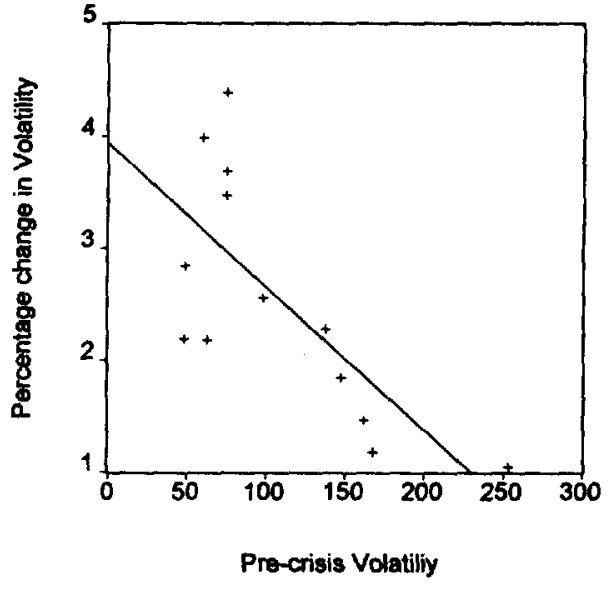

Figure 19

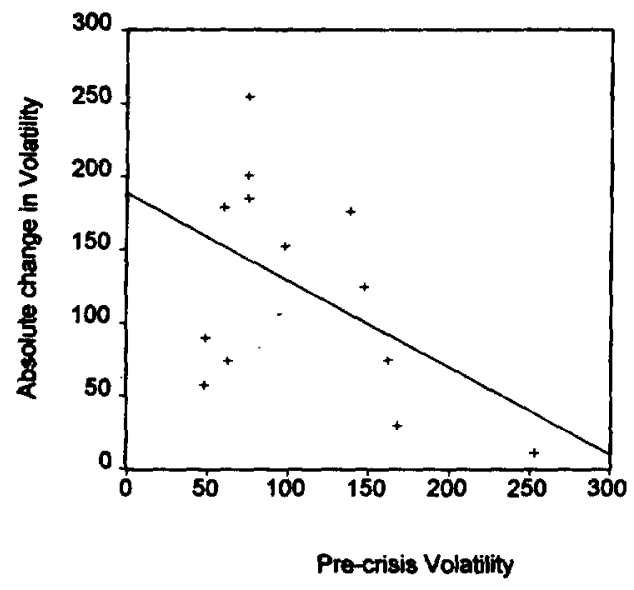

Figure 20

ii) Similarly, figures 21 and 22 below show that also the second implication holds: the mean and the volatility of the risk premium have a positive relation.

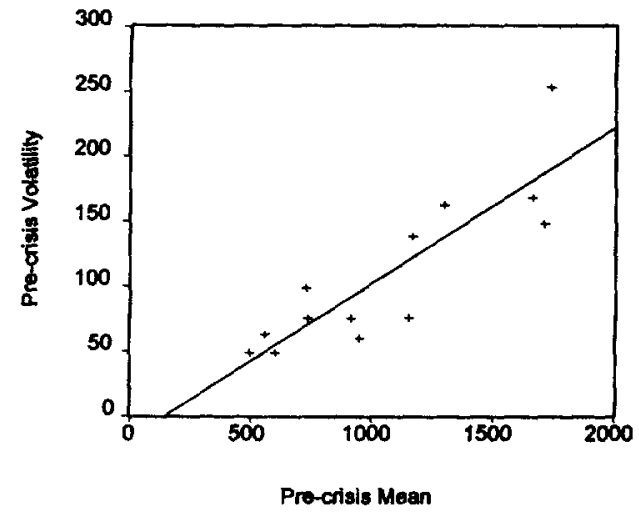

Figure 21

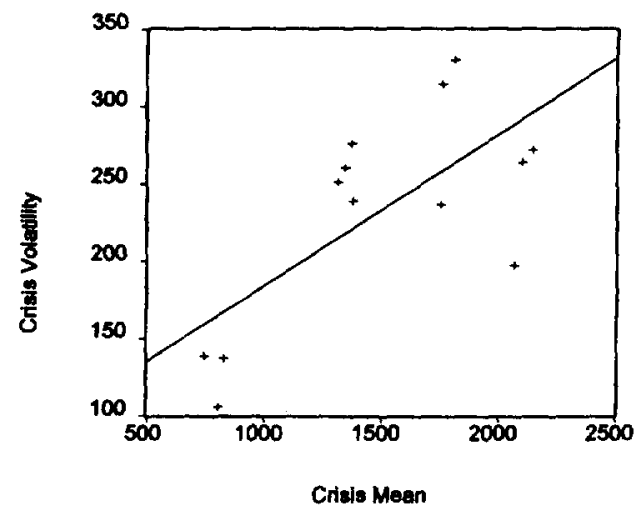

Figure 22

iii) Finally, we try the following experiment to look for evidence supporting the third implication. For both periods pre-crisis and crisis - we rank the countries according to the probability of default (1- $\pi)$ - proxied by the pre-crisis mean of the risk premium - and then we plot the volatility on this rank. For the pre-crisis period the ranking is (from the most likely to the less likely to default): Nigeria, Venezuela, Bulgaria, Ecuador, Argentina, Brazil, Poland, Philippines and Mexico. For the crisis period, we keep the same ranking but we move Mexico from the last to the first position. We report the plots for Par and Discount bonds in figure 23-26. 
Par Bonds

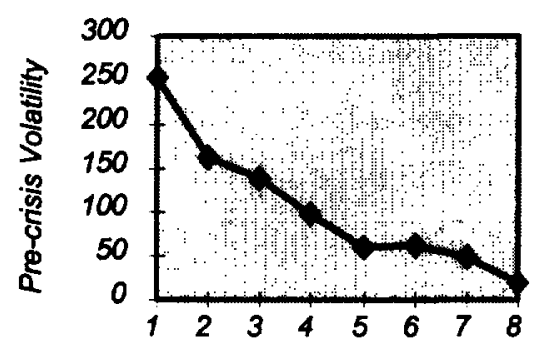

Countries (in order): Nigeria, Venezuela, Ecuador, Argentina, Brazil, Poland, Philippines and Mexico

Figure 23

Par Bonds

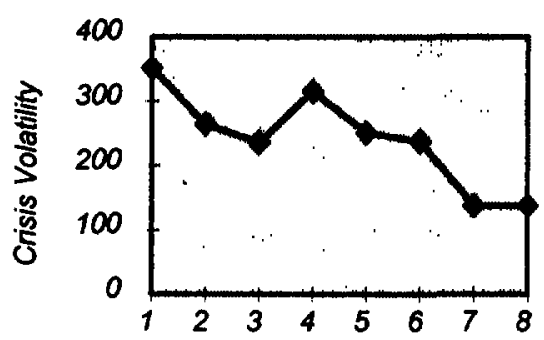

Countries (in order): Mexico, Nigeria, Venezuela, Ecuador, Argentina, Brazil, Poland and Philippines

Figure 25
Discount Bonds

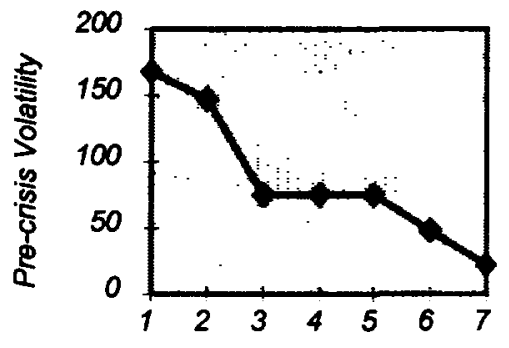

Countries (in order): Venezuela, Bulagaria, Ecuador, Argentina, Brazil, Poland,

Philippines, Mexico

Figure 24

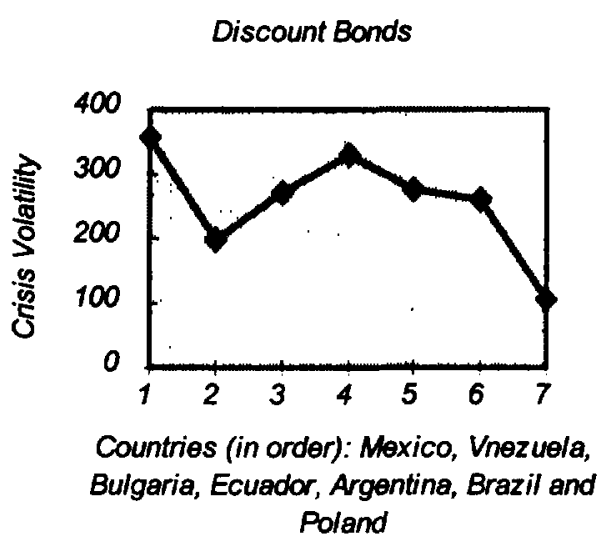

Figure 26

The plots show an evident decrease in the slope of the volatility as a consequence of the increase of the probability of default due to the Mexican crisis. Our third implication is substantially supported.

\section{Conclusions and policy implications}

This paper provides a preliminary understanding of the Brady bond market. The paper has studied the effects of the Mexican crisis on the risk assessment (as measured by the stripped spread) of other Brady countries. Our findings can be summarized as follows:

i) the risk premium (on a single country) has one unit root; this is consistent with the hypothesis that the risk premium reflects new information accruing to the market; 
ii) comovements were stronger during the high volatility period of the Mexican crisis; in particular, in our casestudy on Mexico and Poland, we do not reject the null of cointegration for the period July 94-July 95, but we do reject the null for the period July 95-July 96.

iii) the crisis has had a strong permanent effect on the risk assessment on Mexico (550 bs. pts. circa);

iv) different Brady bonds responded differently to the Mexican crisis: countries with similar pre-crisis mean and volatility reacted in a similar way (in terms of both absolute deviation and degree of comovement with the Mexican bonds). Other factors (regions, oil producers, date of Brady deal) do not explain the observed patterns.

v) there was convergence of volatility during the high volatility period of the Mexican crisis.

These results suggest that traders' behavior when assessing sovereign risk of Brady countries is not constant over time and that it responds to the level of uncertainty in the market. Herd behavior increases with risk, leading to even higher volatility. ${ }^{35}$ Traders have limited information on developing countries, therefore learning spillovers are likely. The joint effect of these two forces can be powerful, as the example of Poland suggests.

The main policy implication of this paper is that systemic risk in the market for developing countries external debt has not completely disappeared. While excess volatility is intrinsic to financial markets when there is herd behavior, comovements are the consequence of poor information only. However, the reaction of the Brady bond market to the Mexican crisis and its aftermath proved its liquidity. ${ }^{36}$

To conclude, the decrease in sovereign risk premium comovements in the second period of our sample could be due to the fact that markets are learning, i.e. acquiring experience and gathering information on the developing countries, so that learning spillovers are less relevant; but it could also signal the absence of any relevant shock to generate such spillover effects, while in fact the market is still vulnerable to country-specific shocks. On this issue further research is needed. ${ }^{37}$

\footnotetext{
${ }^{35}$ An interesting possibility for future research is to look at data on portfolio holdings to see whether there is a convergence in the allocation of funds during periods of high volatility.

36 "It was the middle of October 1991 that the market received the sudden shock that the price rises of the previous 18 months were not immune to gravity. [...] massive selling of Brazilian paper one Friday morning, inspired by JPMorgan in NY, while a massive coup for the bank, left a number of financial institution reeling. Within three weeks the debt was trading at $22 \%$ of face value, and managed to bring down prices across the board. 'What upset the market is that some traders would not come to the phone, and if they did, the prices were wholly unrealistic', says Russell Hanlon, vice president at Chartered WestLB in NY." by Rupert Wright, Trade Finance September 1992 (page 64). But in 1995, after the Mexican crisis: "One thing is that this market demonstrated its resiliency and liquidity. The worst scenario would have been an illiquid market, but people who wanted to sell could', said Michael Chamberlin, executive director of the Emerging Markets Traders Association." by Paul Kilby, Latin Finance N. 70 (page 34).

${ }^{37}$ There is a recent growing literature on exchange rate correlations that analyses to what extent such correlations are explained by a set of fundamentals (for example B. Eichengreen, A.K. Rose and C. Wyplosz (1996), J. Sachs, A. Tornell and A. Velasco (1996)). Having a longer time serie spanning well beyond the period of the Mexican crisis, it would be extremely interesting to do a similar exercise on the sovereign risk premium: regressing cross-country risk premium correlations on a set of fundamentals would let us assess how much of these correlations is explained by observable fundamentals.
} 
BOX 1 - Brady Bonds: a primer

Par and Discount bonds have been by far the most popular options in several Brady agreements. Par bonds are 30 years maturity ( 25 for Philippine Pars) issued at "par", i.e. for the original face value of the loans for which they were exchanged. Par bonds carry a fixed, below market interest rate (relative to the interest rate environment at the time of the issuance). Discount bonds are 30 years maturity floating market interest rate, issued at a discount to original face value of the previously rescheduled loans.

In general, both security types are collateralized as to principal at maturity by US Treasury zero coupon bonds. Par and Discount bonds may possess additional collateral in the form of a cash collateral account usually maintained at the Federal Reserve Bank of NY. The funds in these accounts, which are allowed to be invested in securities rated AA- or better, are maintained in order to pay interest for a specific number of months (usually from 12 to 18 months depending on the country) in the event that the sovereign debtor suspends the interest payments. In effect the collateral provides a "rolling" interest payments guarantee, meaning that if each successive interest payment is made and the collateral is not utilized, it is "rolled" or applied to guarantee the nearest dated unsecured semi-annual interest payment. If the collateral is drawn upon, it is not required to be replaced.

Certain Par and Discount bonds also carry "value recovery" warrants, which give bondholders the opportunity to "recapture" some of the debt and debt service reduction provided in the exchange if the future economic performance and/or the debt servicing capacity of the sovereign debtor improves. For example, in our sample Mexico, Venezuela and Nigeria bonds carry warrants linked to indices of oil export prices or of national oil export receipts.

The value assigned to the principal on Par and Discount bonds is simply the present value of the security used as a collateral. For dollar denominated bonds, the principal is discounted by the risk-free rate of a comparable maturity US Treasury zero-coupon bond.

The interest collateral of a Brady bond is a more complicated component to value since it is uncertain when, if ever, it will be used. This provides an occasion for differences in valuation approaches which arise from assumptions about the probable life of the "roll" of the collateral. One method assumes the limiting case, which ascribes the minimal value to the collateral's current market value, effectively treating it as if there was no life to the "roll" (i.e. default occurs today and collateral is utilized and exhausted to pay the nearest 2 or 3 semiannual interest coupons). Other methods rely on the use of probability models or option pricing formulas to assign probabilities to interest payment default, which are then incorporated in the valuation model.

@To obtain the stripped yield, the value of the principal and interest collateral is calculated as described above, and this notional "market value" of the collateral is subtracted from the current market price. After "stripping" out the values of the principal and interest collateral from the price, an internal rate of return is computed on the non-collateralized contractual cash flows. These non-collateralized interest flows should be discounted by a rate, the stripped yield, that produces a present value which, when added to the collateralized portion of the bond, equals the current market price. The internal rate of return of a Brady bond cash flow with its collateral left intact is simply the bond's implied yield-to-maturity or blended yield.@

The value of the "value recovery" warrants, which are linked to the value of the country's oil exports, is usually ignored in the valuation of the bonds.

Swapping floating-rate coupons for fixed rate equivalents (using either the current LIBOR-based Eurodollar swap curve or forward rate curve) places all Bradies on equal footing with other sovereign instruments. In particular it makes possible to compute the stripped spreads for all bonds.

Source: The 1995 Guide to Brady Bonds. Merrill Lynch, December 61994. 


\section{REFERENCES}

Campbell, J.Y. and P. Perron (1991): "Pitfalls and opportunities: what macroeconomists should know about unit roots", NBER Macroeconomic Annual.

Calvo, G.A. (1996): "Capital flows and macroeconomic management: tequila lesson", University of Maryland, mimeo.

Calvo, S. and C. Reinhart (1996): "Capital flows to Latin America: is there evidence of contagion effects?", Policy Research Working Paper 1619, The World Bank.

Claessens, S. and S. van Wijnbergen (1993): "Secondary market prices and Mexico's Brady deal", Quarterly Journal of Economics, pp. 965-981.

Claessens, S., D. Oks and S. van Wijnbergen (1993): "Interest rates, growth and external debt: the macroeconomic impact of Mexico's Brady deal", mimeo World Bank.

Claessens, S. and G. Pennacchi (1992): "Deriving developing countries repayment capacity from the market prices of sovereign debt", Policy Research Working Paper WPS 1043, The World Bank.

Cohen, D. (1989): Private Lending to Sovereign States, MIT Press.

Cumby, R.E. and M.D.D. Evans (1993): "Measuring current and anticipated future credit: estimates from Brady bonds", Stern School of Business Working Paper EC-93-13, New York University.

Dikey, D. and W.A. Fuller (1981): "Likelihood ratio statistics for autoregressive time series with unit root", Econometrica vol.49.

Dikey, D. and S. Pantula (1987): "Determining the order of differencing in autoregressive process", Journal of Business and Economic Statistics vol. 15.

Doukas, J. (1989): “Contagion effect on sovereign interest rate spreads", Economic Letters 29.

Eaton, J. and M. Gersovitz (1981): "Debt with potential repudiation: theoretical and empirical analysis", Review of Economic Studies 48.

Eichengreen, B. (1989): "The US capital market and foreign lending, 1920-1955", in J.D. Sachs ed.: Developing Country Debt and the World Economy, NBER.

Eichengreen, B. , A.K. Rose and C. Wyplosz (1996): "Contagious currency crisis", CEPR Discussion Paper No. 1453.

Engle, R.E. and C.W.J. Granger: "Cointegration and Error-Correction: representation, estimation and testing", Econometrica 55.

Garbade, K. (1982): Securities Markets, McGraw-Hill.

Hajivassiliou, A.V. (1989): "Do secondary markets believe in life after debt?", in Husain, I. and I. Diwan eds.: Dealing with the Debt Crisis, The World Bank.

IMF (1995): Private Market Financing for Developing Countries.

Merrill Lynch (1994): The 1995 Guide to Brady Bonds. 
Mills, T.C. and A.G. Mills (1991): "The international transmission of bond market movements", Bulletin of Economic Research 43.

Ozler, S. (1993): "Have commercial banks ignored history?", American Economic Review vol. 83 no.3.

Ozler, S. and H. Huizinga (1991): "How factors in creditor countries affect secondary market prices for developing countries debt", Policy Research Working Paper 622, The World Bank.

Sachs, J., A. Tornell and A. Velasco (1996): "Financial crisis in emerging markets: the lessons from 1995", NBER Discussion Paper 5576.

Scharfstein, D.S. and J.C. Stein (1990): "Herd behavior and investment", American Economic Review vol. 80.

Shiller, R. (1989): Market Volatility, MIT Press.

Sims, C.: "Macroeconomics and reality", Econometrica 48.

Stock, J. and M. Watson: "Testing for common trends", Journal of the American Statistical Association 83. 




\section{Policy Research Working Paper Series}

Title

WPS1719 Shifting Responsibility for Social Services As Enterprises Privatize in Belarus

WPS1720 The Distribution of Foreign Direct Investment in China

WPS1721 EU Accession of Central and Eastern Europe: Bridging the Income Gap

WPS1722 Uncertainty, Instability, and Irreversible Investment: Theory,

Evidence, and Lessons for Africa

WPS1723 The Productivity Effects of of Decentralized Reforms: An Analysis of the Chinese Industrial Reforms

WPS1724 Debt Maturity and Firm Performance A Panel Study of Indian Companies

WPS1725 Access to Long-Term Debt and Effects on Firms' Performance: Lessons form Ecuador

WPS1726 Roads, Population Pressures, and Deforestation in Thailand, 1976-89

WPS1727 The Economics of the Informal Sector: A Simple Model and Some Empirical Evidence from Latin America

WPS1728 Regional Labor Markets during Deregulation in Indonesia: Have the Outer Islands Been Left Behind?

WPS1729 Does Mercosur's Trade Performance Raise Concerns about the Effects of Regional Trade Arrangements?

WPS1730 Have Trade Policy Reforms Led to Greater Openness in Developing Countries?

WPS1731 Pension Reform, Growth, and the Labor Market in Ukraine
Author

David Sewell

Harry G. Broadman

Xiaolun Sun

Luca Barbone

Juan Zalduendo

Luis Servén

Lixin Colin Xu

Fabio Schiantarelli

Vivek Srivastava

Fidel Jaramillo

Fabio Schiantarelli

Maureen Cropper

Charles Griffiths

Muthukumara Mani

Norman A. Loayza

Chris Manning

Alexander Yeats

Shuby Andriamananjara

John Nash

Michelle Riboud

Hoaquan Chu

B. Moore
February 1997

R. Martin 39026

Contact

for paper

February 1997

C. Lawrence 32216

February 1997 J. Grigsby 82423

L. Barbone 32556

February $1997 \quad$ E. Khine 37471

P. Sintim-Aboagye 38526

February 1997

B. Moore 38526

February 1997 38526

February 1997

A. Maranon 39074

February 1997

J. Israel 85117

February 1997 J. Ngaine 37947

February 1997

J. Ngaine 37959

February 1997

R. Hablero 33971 


\section{Policy Research Working Paper Series}

\begin{tabular}{|c|c|c|c|c|}
\hline & Title & Author & Date & $\begin{array}{l}\text { Contact } \\
\text { for paper }\end{array}$ \\
\hline WPS1732 & $\begin{array}{l}\text { Agricultural Trade and Rural } \\
\text { Development in the Middle East } \\
\text { and North Africa: Recent Development } \\
\text { and Prospects }\end{array}$ & $\begin{array}{l}\text { Dean A. DeRosa } \\
\text { its }\end{array}$ & February 1997 & $\begin{array}{l}\text { J. Ngaine } \\
37959\end{array}$ \\
\hline WPS1733 & $\begin{array}{l}\text { The Usefulness of Private and Public } \\
\text { Information for Foreign Investment } \\
\text { Decisions }\end{array}$ & $\begin{array}{l}\text { Yuko Konoshita } \\
\text { Ashoka Mody }\end{array}$ & February 1997 & $\begin{array}{l}\text { R. Reff } \\
34815\end{array}$ \\
\hline WPS1734 & $\begin{array}{l}\text { Are Markets Learning? Behavior in } \\
\text { the Secondary Market for Brady } \\
\text { Bonds }\end{array}$ & $\begin{array}{l}\text { Luca Barbone } \\
\text { Lorenzo Forni }\end{array}$ & February 1997 & $\begin{array}{l}\text { L. Barbone } \\
32556\end{array}$ \\
\hline
\end{tabular}

